\title{
ANACINT/PP.- Mi\%38
}

\section{LEACHING PATTERNS AND SECONDARY PHASE FORMATION \\ DURING UNSATURATED LEACHING OF $\mathrm{UO}_{2}$ AT $90^{\circ} \mathrm{C}^{\star}$}

by

David J. Wronkiewicz, John K. Bates, Thomas J. Gerding; Ewald Veleckis, and Benjamin S. Tani

$\operatorname{lng} 211004$

ARGONNE NATIONAL LABORATORY

Chemical Technology Division

9700 South Cass Avenue

Argonne, IL $60439-4837$

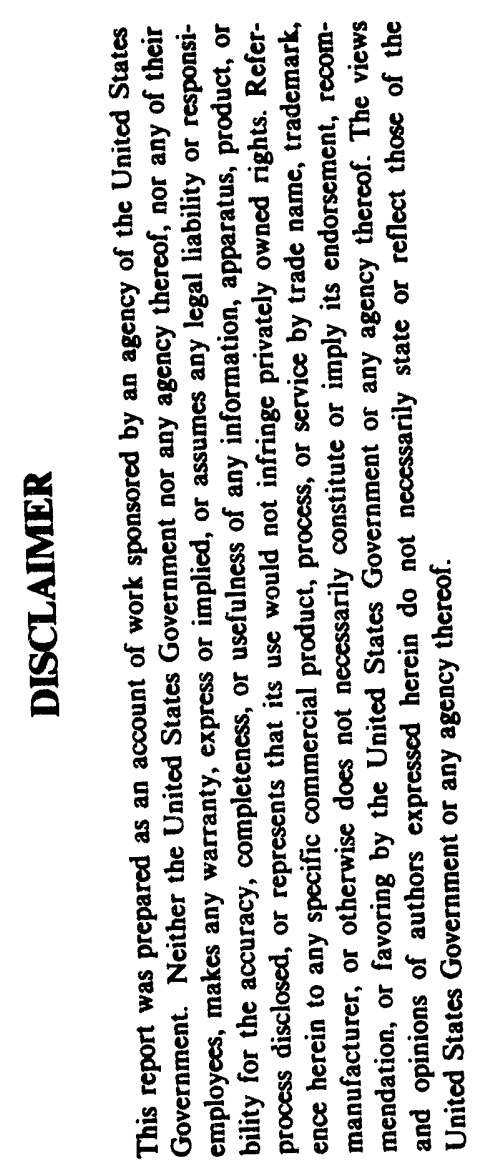

The submitted manuscript has been authored
by contractor of the U.S. Government
under contract No. W-3t-109-ENG-38.
Accordingly, the U.S. Government retains a
nonexclusive, royalty-free license to publish
or reproduce the published form of this
contribution, or allow others to do so, for
U.S. Government purposes.

November 1991

*Work supported by the U.S. Department of Energy, Office of Civilian Radioactive Waste Management, Yucca Mountain Project, under subcontract to Lawrence Livermore National Laboratory, SANL 910-007.

\section{MASTER}




\section{ABSTRACT}

Wronkiewicz, D. J., Bates, J. K., Gerding, T. J., Veleckis, E., and Tani, B.S., 1990. Leaching patterns and secondary phase formation during unsaturated leaching of $\mathrm{NO}_{2}$ at $90^{\circ} \mathrm{C}$

Experiments are being conducted that examine the reaction of $\mathrm{UO}_{2}$ with dripping oxygenated ground water at $90^{\circ} \mathrm{C}$. The experiments are designed to identify secondary phases formed during $\mathrm{UO}_{2}$ alteration, evaluate parameters controlling $U$ release, and act as scoping tests for studies with spent fuel. This study is the first of its kind that examines the alteration of $\mathrm{UO}_{2}$ under unsaturated conditions expected to exist at the proposed Yucca Mountain repository site.

Results suggest that the $\mathrm{UO}_{2}$ matrix will readily react within a few months after being exposed to simulated Yucca Mountain conditions. A pulse of rapid $U$ release, combined with the formation of dehydrated schoepite on the $\mathrm{UO}_{2}$ surface, characterizes the reaction between one to two years. Rapid dissolution of intergrain boundaries and spallation of $\mathrm{UO}_{2}$ granules appears to be responsible for much of the $U$ released during this interval. Differential release of the $\mathrm{UO}_{2}$ granules also may be responsible for much of the variation observed between duplicate experiments. Less than 5 wt \% of the released $U$ remains in solution or in a suspended form, while the remaining settles out of solution as fine particles or is reprecipitated as secondary phases. Subsequent to the pulse period, $U$ release rates decline and a more stable assemblage of uranyl silicate phases are formed by incorporating cations from the ground water leachant. Uranophane, bcltwoodite, and sklodowskite appear as the final solubility limiting phases that form in these tests. This observed paragenetic sequence (from 
uraninite to schoepite-type phases to uranyl silicates) is identical to those observed in weathered zones of natural uraninite occurrences. The combined results of this study indicate that the release of radionuclides from spent fuel may not be limited by $U$ solubility constraints, but that spallation of particulate matter may be an important, if not the dominant release mechanism affecting release.

\section{INTRODUCTION}

Densely welded and devitrified ash-flow tuff beds at Yucca Mountain, Nevada, are currently being investigated as a potential site for permanent disposal of high-level nuclear waste. The proposed repository horizon is located in an unsaturated environment, approximately 200 to $400 \mathrm{~m}$ above the

present water table $(S C P, 1988)$. Matrix flow is expected to be the dominant water transport mechanism within the vadose zone, with limited amounts of water being available to corrode the waste packages and transport the radionuclides. In the event of eventual breaching of the waste containers, the waste forms will most likely be exposed to humid air and limited amounts of dripping water.

The Unsaturated Test Method (UTM) has been specifically designed to investigate the reaction between water and simulated waste forms under potential repository conditions (Bates and Gerding, 1985). This method involves periodically dripping small amounts of water on samples that are maintained in temperature-regulated stainless steel test vessels. After contacting the sample, the injected water is allowed to migrate down the sides of the sample, drip from the bottom, and collect in the test vessel. 
The UTM thus simulates an environment where the waste container develops breaches along its top and bottom, allowing free flow of water through the container and limited contact time with the waste form.

Previous UTM studies conducted with simulated waste glass have found that the increased SA/V ratio (surface area of the waste form to volume of liquid) may accelerate reactions that transform glass into secondary phases (Bates and Gerding, 1990). The relatively small volume of liquid contacting the sample is quickly saturated with aqueous species derived from the dissolving glass. The secondary phases that subsequently form may lower the activity of specific ion(s) in the solution, and therefore, may have the potential to increase the driving force of a potential dissolution reaction.

The present experiments are being conducted to demonstrate the feasibility of performing the UTM with spent fuel. Because direct testing of spent fuel is difficult due to its high radioactivity, these tests are being undertaken using unirradiated $\mathrm{UO}_{2}$ as a surrogate. While it is recognized that these experiments cannot be used to predict spent fuel behavior, the reaction processes occurring in the breakdown of the $\mathrm{UO}_{2}$ matrix and spent fuel may be comparable, since spent fuel contains $>95 \% \mathrm{UO}_{2}$ (Johnson and Shoesmith, 1988). Therefore, the gross processes observed in the $\mathrm{UO}_{2}$ experiments could be relevant to spent fuel testing, especially with respect to the identification of secondary mineral phases and waste form degradation mechanisms. 


\section{EXPERIMENTAL}

\subsection{Experimental Apparatus}

Sample pellets were fabricated from pressed-sintered $\mathrm{UO}_{2}$ granules with a natural isotopic abundance of $U$. The overall oxygen/metal ratio is determined to be $2.000=0.002$ by measuring the weight difference between a sample prior to and after heating to $850^{\circ} \mathrm{C}$. Atmospheric exposure during storage may have resulted in oxidation of the samples, however, at ambient temperatures, this oxidation should be kinetically limited to the top few monolayers of the surface (Anderson et al., 1955; Tremaine et al., 1981). Trace element concentrations in the pellets are $<1 \mathrm{ppm}$ each for $\mathrm{SC}, \mathrm{F}, \mathrm{Rb}$, $\mathrm{Sr}, \mathrm{Cs}, \mathrm{Pb}, \mathrm{Co}, \mathrm{V}, \mathrm{K}, \mathrm{Mn}, \mathrm{Ba}, \mathrm{Ti}, \mathrm{Y}, \mathrm{Zr}, \mathrm{Mg}, \mathrm{Cr}, \mathrm{P}, \mathrm{Na}, \mathrm{S}$, and the rare earth elements; whereas $\mathrm{B}, \mathrm{Si}, \mathrm{Ca}, \mathrm{Ni}, \mathrm{Cu}$, and $\mathrm{Al}$ concentrations are between 1 and $5 \mathrm{ppm} ;$ and $\mathrm{Cl}, T \mathrm{Th}$, and $\mathrm{Fe}$ concentrations equal to 10, 15, and $20 \mathrm{ppm}$, respectively.

The pellets were prepared for testing in one of three ways: (1) they were cut into a stack of eleven 13.9 by $1.75 \mathrm{~mm}$ thick wafers, (2) crushed in a mortar and pestle to collect $-60+80$ mesh fraction, or (3) cut into a stack of three 13.9 by $10 \mathrm{~mm}$ thick cylinders (Wronkiewicz et al., 1991a). These configurations were used to assess the effect of changing SA/V ratios on $\mathrm{UO}_{2}$ dissolution. Samples were clad in $0.38-\mathrm{mm}$ thick Zircaloy-4 tubing which has been cut into different lengths to accommodate the various sample configurations. Samples were assembled with the sides encased by the Zircaloy cladding and the bare $\mathrm{UO}_{2}$ surfaces exposed on the tops and bottoms. Crushed $\mathrm{UO}_{2}$ grains of configuration \#2 were sandwiched between two 13.9 by $1.75 \mathrm{~mm}$ wafers. 
The leachant for the experiments is ground water from the J-13 well located near Yucca Mountain, Nevada. This water has been equilibrated with core samples from the Topopah Springs Member of the Paintbrush Tuff by soaking $10 \mathrm{~g}$ of crushed tuff in $1 \mathrm{~L}$ of water for two weeks at $90^{\circ} \mathrm{C}$, followed by filtration and dark storage. The composition of the equilibrated water (EJ-13 water) is presented in Table 1.

The experiments are housed in stainless steel (304L) vessels that provide a stable atmosphere for the collection and containment of the leachate and support of the specimen assembly (Fig. 1). The Zircaloy cladding rests directly on a perforated Teflon TM stand, maintaining $\sim 3 \mathrm{~mm}$ of space between the bottom $\mathrm{UO}_{2}$ pellet and the stand. A small amount of EJ-13 water $(0.20 \mathrm{~mL})$ is initially deposited in the bottom of the vessel to provide for a humid atmosphere. The vessel is then assembled, hermetically sealed, weighed, placed in a $90 \pm 1^{\circ} \mathrm{C}$ oven, and connected to the water injection line. Premeasured quantities of EJ-13 water are periodically injected onto the top surface of the specimen via the stainless steel/TeflonTM injection line. Air is next flushed through the line to insure that most water passes through the injection line and contacts the sample.

Duplicate experiments were initiated for the three previously listed configurations with water injection rates of $0.075 \mathrm{~mL}$ every 3.5 days (7.8 mL/yr; Table 2). An additional pair of experiments was performed for the three cylinder configuration at an injection rate of $0.0375 \mathrm{~mL}$ every 7 days $(1.95 \mathrm{~mL} / \mathrm{yr})$. One test from each of the four pairs of experiments has been terminated while the remaining four experiments are ongoing. 


\subsection{Analytical Procedure}

A semi-continuous leaching mode was adopted for the experiments with initial 6.5-week sampling intervals that were later lengthened to 213 weeks to provide for larger leachant volumes. At predetermined times, experiments were interrupted to collect the accumulated liquid and to visually examine the $\mathrm{UO}_{2}$ specimen for signs of alteration. Solution volumes were determined by measuring the weight difference of the test vessel between the beginning and end of each period. The average recovered fraction of injected fluid is $\sim 75 \%$, with water loss probably occurring during the injection process, or from evaporative, osses during vessel disengagement and sampling, or through leakage from the pressurized vessel.

After disengaging, rapid cooling, and weighing of the test vessel, the $\mathrm{UO}_{2}$ specimen assembly was lifted from the vessel and placed in a humidity chamber to prevent dehydration. Initially, the small quantities of recovered leachate limited solution analyses to an "acid strip" $U$ solution that was produced by diluting the leachant solution with deionized water, acidifying with $\mathrm{HNO}_{3}$ (Ultrex), and soaking the vessel for ten minutes at room temperature. Total uranium release (soluble + insoluble fractions) was determined from the acid strip analyses. As the sampling intervals were lengthened and sufficient quantities of leachant collected, aliquots were withdrawn directly from the pre-acid strip solution for anion $(0.5 \mathrm{~mL})$, uranium $(0.1 \mathrm{~mL}), \mathrm{pH}(0.1 \mathrm{~mL})$, and carbon $(0.5 \mathrm{~mL})$ analyses. The "acid strip" solutions were also submitted for cation analysis at this time. After sampling, the test vessel and TeflonTM stand were rinsed and dried, an additional $0.20 \mathrm{~mL}$ of EJ-13 water was added to the vessel bottom, and the test specimen and vessel were reassembled to renew the next cycle. 
Analytical methods used for the solution samples were as follows: $U$ was analyzed by the Atomic Fluorescence Spectroscopy, cations by Inductively Coupled Plasma/Atomic Emission Spectrometry (ICP/AES), anions by Ion Chromatography (IC), carbon with the Dohrmann Total Carbon Analyzer, and $\mathrm{pH}$ with the Brinkmann Metrohm Meter. Accuracy of results are within $3-10 \%$ of the amount present in the analyzed solution. Precision, as determined by multiple analyses of a single sample and reported as the coefficient of variation (SD/Mean $\times 100)$, is $\angle 5 \%$ for $U$.

The UTM defines all $U$ that has migrated from the $U 0_{2}$-Zircaloy assembly as having been released. This includes $U$ in solution and colloidal suspension, particulate matter, and $U$ sorbed onto the vessel walls and TeflonTM stand. Uranium from the latter two sources is largely recovered during the 10-min acid strip. Uranium contributions introduced with the EJ-13 water are negligible (Table 1). The final acid strip step for terminated experiments was performed overnight at $90^{\circ} \mathrm{C}$ in order to fully remove all precipitated $U$.

Analysis of surface phases was performed using a combination of techniques, including scanning electron microscopy-energy dispersive spectrometry (SEM/EDS), X-ray diffraction (XRD), and both reflected and transmitted optical microscopy. Samples were first analyzed by carefully mapping and photographing the surfaces using a reflected-light stereomicroscope with magnification up to $150 x$. Phases of interest were next removed from the surface for XRD analysis and/or transmitted optical microscopy. Individual picked phases or entire pellet surfaces were finally examined by SEM/EDS. 
Identification of some secondary uranyl phases is quite complex. For example, SEM/EDS analysis will not routinely determine elements below $Z=11$. Thus, differentiation between oxide and carbonate phases cannot be made utilizing this technique alone. Energy interferences may also mask the presence of some elements when SEM/EDS analyses are made. In particular, the overlap of $U M_{\beta}$ and $K K_{\alpha}$ lines precludes an accurate determination of the presence of $K$ in many uranium minerals. XRD patterns also overlap for many uranyl oxide hydrates (UOH) minerals, causing difficulties in differentiation between schoepite, becquerelite, and compreignacite. The very fine-grained nature of these phases also complicates extraction and isolation of individual grains for XRD analysis.

Fortunately, differentiation of many $\mathrm{UOH}$ minerals can be made utilizing a combination of methods. For example, becquerelite is identified by combining XRD evidence for a $U O H$ structure, EDS evidence indicating the presence of $\mathrm{Ca}$ and $U$, and a distinct crystal morphology. Distinguishing between schoepite and compreignacite is, however, more tenuous. These two minerals display similar XRD patterns, overlapping $U$ and $K$ EDS spectra, and polymorphous mineral behavior. Ion probe mass spectrometry analysis has been employed for a limited number of these grains to aid in their identification.

A final problem that complicates the identification of some UOH phases is metastability. Schoepite may undergo spontaneous and irreversible dehydration at room temperatures, even when just mechanical pressure is applied to the crystals (Christ and Clark, 1960). Evidence for dehydration includes amber-brown cores of schoepite encapsulated in golden-yellow rims of dehydrated schoepite, and the formation of small dehydration tubes in dehydrated schoepite. 


\section{RESULTS}

\subsection{Total Uranium Release}

Although the total quantity of $U$ released from individual samples typially varies by an order of magnitude, the overall release patterns are similar between most experiments (Fig. 2). For example, samples \#1 and \#2 initially release between 10 to $25 \mu \mathrm{g}$ of $U$ during each of the first two sampling intervals (Table 2). Release rates increased substantially from 19.6 to 26 weeks, where 200 to $450 \mu \mathrm{g}$ of $U$ was released during each sampling interval. This initial increase is followed by a transient decline during the following two to three intervals, where only 40 to $130 \mu \mathrm{g}$ were released. A period of rapid pulsed $U$ release followed next, with release rates that dominate the overall patterns of the experiments. For experiments \#1 and \#2, measured $U$ releases ranged between 1000 and $2200 \mu \mathrm{g}$ per sample interval. This pulse period accounts for approximately $65 \%$ of the total $U$ released from the samples over a time interval that spans $<15 \%$ of the experiment duration.

There are notable variations between the timing and magnitude of the pulsed release for different samples. For example, the pulse in experiment \#8 occurred after 78 weeks, whereas in experiment \#6 it occurred between 33 to 78 weeks (Table 2; Fig. 2). Experiment \#3 is the only sample that does not exhibit a sharply defined pulse release interval. Uranium release from this sample has remained relatively low throughout the duration of the test, exhibiting only a broad low-amplitude increase from 45 to 211 weeks. Experiments \#4 and \#8 were also terminated during their pulse intervals, so the total quantity of released $U$ and the time lengths for their respective periods are considered minimums. 
After approximately 1.5 to 2 years, $U$ release levels decline to an apparent "steady-state" that has continued up to the present 4.5 years of reaction (Fig. 2). Release rates during this interval are similar to those that characterize the samples during the initial dissolution stage.

After 3.5 years of reaction, $U$ analyses were also made on unacidified leachate aliquots (solution $U_{;}$Table 1). These results indicate the proportion of uranium released in a soluble or suspended particulate form. Excluding the anomalous value from the 210.6-week sample 6 analyses, the concentration of $U$ in these solutions averages $2.3 \neq 1.1 \mathrm{mg} / \mathrm{L}$, accounting for $\sim 5$ mole\% of the total released.

\subsection{Solution Chemistry}

Due to the small volumes of the leachate collected, only a small number of determinations were performed for cation, anion, $\mathrm{pH}$, and carbon. Values reported in Table 1 have been corrected for species present in the $0.2 \mathrm{~mL}$ of EJ-13 solution added initially during each test interval. These values thus reflect concentrations in the leachate after interaction with the $\mathrm{UO}_{2}$ test assembly.

Solution $\mathrm{pH}$ values decrease from 8.2 for injected EJ-13 water, to $6.9 \neq 0.5$ for the solutions recovered from the test vessels. All pH measurements were made at $25^{\circ} \mathrm{C}$, with the determinations being made as soon as possible after aliquots had been extracted from the leachate solution.

Total carbon concentrations remain relatively constant with organic carbon species (TOC) increasing and inorganic carbon species (TIC) decreasing relative to those of the initial EJ-13 composition (Table 1). Analyses from the 4.5-year samples indicate that formic and oxalic acid 
have become important components of the leachate solutions, representing between 50 to $100 \%$ of the increased noted in the roc fraction. These ions are not present in any detectable concentrations in EJ-13 water.

Anion and cation determinations were made only after two years of testing (Table 1). A limited number of analyses suggest that concentrations of $\mathrm{Cl}^{-}, \mathrm{NO}_{3}^{-}$, and $\mathrm{SO}_{4}^{-2}$ ions increase slightly, whereas $\mathrm{HCO}_{3}^{-}$ decreases relative to EJ-13. The 182.6-week results from experiment \#5 show unusually high anion concentrations. The cause for this anomaly is uncertain, but may be related to the large dilution factors required for analysis of the small fraction of liquid recovered from this sample. Concentrations of $B$ and $L i$ do not change significantly, sodium concentrations are variable, and $\mathrm{Ca}, \mathrm{Mg}$, and $\mathrm{Si}$ are significantly depleted relative to the original EJ-13 solution. Calcium exhibits the largest decrease, with concentrations that are typically an order of magnitude less than the starting fluid.

\subsection{Surface Analyses}

Extensive development of secondary alteration phases is visually observed in all experiments, with phases being concentrated on the top and bottom $\mathrm{UO}_{2}$ surfaces, and pellet-cladding gap areas. As previously noted, four of the tests (samples \#1,\#4, \#5, and \#8) have been terminated to allow for detailed surface examination. Each sample developed a unique appearance depending on the disposition of water after it contacted the surface. Samples terminated after 3.5 years (long-term samples) have developed precipitate ring patterns suggesting that water drops were restricted near the center of the pellet surfaces (Fig. $3 a$ and $b$ ). There 
is less evidence for restricted water flow on the short-term samples, with mineral zonation being poorly developed on these surfaces. Crystalline phases from the short-term samples also appear to be of a single morphology, while the long-term samples are characterized by the development of several precipitate types, especially on their top surfaces.

Secondary phases identified from the sample surfaces, along with their compositions and distinguishing morphological characteristics, are listed in Table 3. Descriptions of these phases and exposed portions of the $\mathrm{UO}_{2+x}$ surface are as follows:

\subsubsection{Uranium Oxide Phases}

\subsubsection{The $\mathrm{U}_{2} 2+x$ Surface}

Relative to the fresh $\mathrm{UO}_{2}$ surfaces (Fig. 4a), exposed portions of oxidized surfaces $\left(\mathrm{UO}_{2}+x\right.$, where $x$ ranges from $>0$ to 0.67$)$ provide evidence that records previous dissolution events. The top surface of sample \#4 appears to be altered to the greatest extent, with many of the grains displaying intergrain boundaries so pervasively corroded that they are nearly detached from the surface (Fig. 4b). Grains are also highly pitted, with the individual pits often coalescing to form sharp-edged ridges and jagged canyons. The bottorn surface of sample \#4 displays more subdued evidence for intergranular corrosion. In a few locations on this surface, the corroded $\mathrm{UO}_{2+x}$ grains apparently have been dislodged, exposing relatively unaltered underlying grains (Fig. 4C).

The remaining samples appear to be less extensively corroded than sample \#4. Sample \#8 (not shown) is characterized by fairly well-developed surface pits, whereas intergranular corrosion appears to be minimal. The rapid corrosion of this sample, as evidenced by the large $U$ release rates 
(Fig. 2b), is, therefore, not readily apparent during SEM examination of this sample surface. Sample \#5 has less surface pitting, but displays corroded intergrain boundaries and a hummocky surface texture that is quite distinct from the previously described samples (Fig. 4d). EDS spectra from the $\mathrm{UO}_{2}$ and $\mathrm{UO}_{2+x}$ surfaces are dominated by $U$, with possible traces of $\mathrm{K}$ and $\mathrm{Si}$ also being present in the $\mathrm{UO}_{2+x}$ surfaces (Figs. $5 \mathrm{a}$ and $5 \mathrm{~b}$ ).

\subsubsection{Uranium-Rich Particulates}

An abundance of fine particles occur on secondary mineral phases, exposed $\mathrm{UO}_{2+x}$ surfaces, and TeflonTM support stands of the 1.5- and 2:25-year samples (Fig. 6a). SEM/EDS examinations indicate a U-dominated composition, identical to that of the $\mathrm{U}_{2+x}$ surface. Particles typically range from 0.5 to $15 \mu \mathrm{m}$ in diameter and have angular to subrounded edges. These grains are ubiquitous on the top surface of sample \#4, while being less abundant on the bottom, especially in locations where some secondary phases show evidence for dissolution. Particulate matter is nearly absent on sample \#5, which has been reacted for 3.5 years. These particles thus occur in the greatest concentration for samples that were terminated during the pulsed uranium release period.

\subsubsection{Uranyl Oxide Hydrates (UOH)}

\subsubsection{Dehydrated Schoepite $\left(\mathrm{UO}_{2} \cdot 0.8 \mathrm{H}_{2} \mathrm{O}\right)$}

Dehydrated schoepite is the dominant alteration phase present on samples that have been reacted for up to 2.25 years. On samples \#4 and \#8, dehydrated schoepite forms extensive crystal mats that blanket large portions of the $\mathrm{UO}_{2+x}$ surfaces and the pellet-Zircaloy cladding gap areas. This phase is also common on the sides, bottoms, and interpellet regions of 
samples \#1 and \#5 while it is relatively rare on the top surfaces. The most reliable criteria for dehydrated schoepite identification is a diagnostic $5.11 \AA$ basal spacing from XRD analysis and a uranium-only spectra obtained by EDS analysis (Table 4; Fig. 5c). In some instances, positive identification can be often complicated by polymorphous and pseudomorphous crystalline habits, solid solution chemistry, multiphase stacking of different $\mathrm{UOH}$ minerals, and the ability to form spontaneously from dehydrating schoepite (Christ and Clark, 1960; Peters, 1965; Smith, 1984).

Dehydrated schoepite commonly appears as drusy surface coatings of bright yellow to green, euhedral, tabular, "boat-shaped" crystals (Figs. 6a,6b, and $6 c$ ). These grains generally are singly terminated, but double terminations are found on occasion. Crystals are between 5 to $100 \mu \mathrm{m}$ in length, with thicknesses ranging from $0.5 \mu \mathrm{m}$ for incipient stellar-shaped accumulations, to $20 \mu \mathrm{m}$ for crystals located in interpellet regions of sample \#5. Stacked masses of crystalline plates often display a concave curling habit, where the overlying plates progressively show increased angles of intersection with respect to the $\{001\}$ surface of the lowermost crystal (Fig. 6a). In transmitted light, the crystals are canary-yellow in color, occasionally with a deep red core. Small tubes and vesicles are occasionally observed, and may record the presence of water escape channels formed during dehydration events (Christ and Clark, 1960).

Dissolution pits formed on dehydrated schoepite crystals from the bottom surface of sample \#4 record a period of phase dissolution in this region (Fig. 6C). Crystals displaying terraced surficial topographies also are found, with the patterns possibly arising from differential corrosion of varied compositional layers. 


\subsubsection{Schoepite $\left(\mathrm{UO}_{3} \cdot 2 \mathrm{H}_{2} \mathrm{O}\right)$ and Compreignacite $\left(\mathrm{K}_{2} \mathrm{U}_{6} \mathrm{O}_{19} \cdot 11 \mathrm{H}_{2} \mathrm{O}\right)$}

Schoepite and/or compreignacite have been identified on the top surfaces of samples \#1 and \#5 by SEM and XRD analysis. These phases appear as yellow stacks of "pancake-like" accumulations of pseudohexagonal plates or as fine grain crystalline powders (Fig. 6d). On the top surface of sample \#5, the stacked-plates have fused into a semicontinuous mat of intergrown crystals. Where found, these phases are often intergrown with compreignacite, soddyite, and boltwoodite.

Differentiation between schoepite and compreignacite is complicated by similar XRD patterns, EDS spectral interferences between $U$ and $K$, and potential for solid solution chemistry within the $\mathrm{UOH}$ mineral group (Table 4; Smith, 1984). Enrichment of $\mathrm{K}$ relative to unaltered $\mathrm{UO}_{2}$ is indicated by ion probe analysis on a single crystal extracted from sample \#5. Further quantitative analysis will be required to determine whether this enrichment will satisfy the structural formula requirements for $K$ in compreignacite.

\subsubsection{Becquerelite $\left(\mathrm{CaU}_{6} \mathrm{O}_{19} \cdot 1 \mathrm{OH}_{2} \mathrm{O}\right)$}

Becquerelite is abundant on the top surfaces of samples \#1 and \#5, occurring as large (up to $250 \mu \mathrm{m}$ ) yellow tabular blocks (Fig. 6e). Identification is based on the characteristic UOH group XRD pattern, the presence of $\mathrm{Ca}$ in the EDS spectra, and the distinctive rectangular $\{001\}$ crystal face (Table 4; Fig. 5e). Poor resolution of Ca peaks in the EDS spectra of becquerelite, relative to those of uranophane, may be attributed to the higher $U / C a$ ratio of becquerelite (for example, compare Figs. 5e 
and $5 \mathrm{~g}$ ). Nearly all becquerelite crystals examined from sample \#5 display sharp-edged dissolution pits, indicating that this phase may have been dissolving when the experiment was terminated.

\subsubsection{Uranyl Silicates}

\subsubsection{Soddyite $\left(\mathrm{U}_{5} \mathrm{Si}_{2} \mathrm{O}_{19} \bullet 6 \mathrm{H}_{2} \mathrm{O}\right)$}

Soddyite has been identified as a minor alteration product on the top and bottom surfaces of samples \#4, \#5, and \#8. Grains appear as light green to white colored buttons or crust-like masses of crystals. Soddyite is readily identified by the appearance of several distinctive XRD peaks and $\mathrm{Si}$ and $U$ EDS spectra (Fig. 5f). EDS spectra also indicate that minor $K$ may be present, although the $K$ peak response is not any larger than that of the altered $\mathrm{UO}_{2+x}$ surface and schoepite (compare Figs. $5 f$ with $5 b$ and $5 c$ ). This phase may exhibit polymorphous behavior, with crystalline forms ranging from euhedral bladed crystals (with or without "comb-like" serrated edges), fine-grained $(<5 \mu \mathrm{m})$ prisms, very fine-grained powder or drusy masses, and surface coatings over previously deposited grains (Figs. 6f, $6 \mathrm{~g}$, and $6 \mathrm{~h})$. Soddyite is also observed to form in place of dehydrated schoepite in locations where the latter phase has undergone dissolution.

\section{3 .3 .2 Uranophane $\left(\mathrm{Ca}\left[\mathrm{UO}_{2}\right]_{2}\left[\mathrm{SiO}_{3} \mathrm{OH}\right]_{2} \cdot 5 \mathrm{H}_{2} \mathrm{O}\right)$}

Uranophane is the most common phase observed on the top surfaces of samples \#1 and \#5, yet it is conspicuously absent from the sides and bottoms of these samples and from samples that were terminated prior to 2.25 years. Uranophane occurs as white to intermixed white and yellow acicular crystals. Morphologically, this phase is identical to 
boltwoodite, but the two minerals can be readily distinguished by their distinctive XRD and EDS spectra (Table 4; Figs. $5 \mathrm{~g}$ and $5 \mathrm{~h}$ ). Uranophane needles accumulate in several modes, including rare isolated individual crystals, flat-lying continuous mats of variable crystal densities, dense hummocky mats of crystal bundles, and stellar arrangements of individual crystals (Figs. 6e, 6i, and $6 j$ ).

Mineral relationships generally suggest that uranophane precipitated after schoepite, dehydrated schoepite, and becquerelite. For example, on sample \#5, acicular clumps of uranophane form within dissolution pits that have developed on becquerelite (Fig. $6^{n}$ ). This association suggests that the $U$ in uranophane may have been derived from dissolving becquerelite. More rare occurrences show uranophane intergrown with becquerelite, suggesting that occasionally the two phases may have coprecipitated.

\subsubsection{Boltwoodite $\left(\mathrm{K}\left[\mathrm{H}_{3} \mathrm{O}\right] \cup \mathrm{O}_{2}\left[\mathrm{SiO}_{4}\right] \cdot \mathrm{nH}_{2} \mathrm{O}\right)$}

Like uranophane, boltwoodite is only found on the top surfaces of samples \#1 and \#5. Boltwoodite displays an acicular crystal habit identical to uranophane, but can be readily distinguished by its XRD pattern and $U, K$, and Si bearing EDS spectra (Table 4; Fig. 5h). The needles are white in color, and accumulate as continuous flat-lying mats of variable crystal densities. Uranophane and boltwoodite display both spatial and temporal interrelationships, with boltwoodite occupying the outermost positions on the surface and overlying uranophane where the two phases coexist. 


\subsubsection{Sklodowskite $\left(\mathrm{Mg}\left[\mathrm{UO}_{2}\right]_{2}\left[\mathrm{SiO}_{3}\right]_{2}[\mathrm{OH}]_{2} \cdot 5 \mathrm{H}_{2} \mathrm{O}\right)$}

Sklodowskite is extremely rare, only being detected on the top surface of sample \#1. Crystals display an acicular habit, but are not as elongated as the uranophane and boltwoodite needles (Fig. 6k). EDS spectra indicate that $U, M g$, and Si are present, while XRD patterns are spotty, making positive identification difficult to achieve (Table 4; Fig. 5i).

\subsubsection{Non-Uranium-Bearing Minerals}

Fluoropolymers were found on the top surfaces of most samples, especially on the outer perimeters of samples reacted for $>2.25$ years. These grains appear as white feathers and gray platy-like masses (Fig. 61). Samples were collected for XRD, SEM/EDS, and Fourier transform infrared spectroscopy (the latter performed by DuPont Corp.). Although the exact type of fluoropolymer present could not be discerned, the patterns obtained closely matched those from samples collected from TeflonTM stands. These fluoropolymers were apparently produced as abrasion products from the Teflon TM gaskets on the stainless steel vessel caps. These grains are not involved in the $\mathrm{UO}_{2}$ reactions as the particles appear to be inert on the sample surfaces, and total carbon $(T O C+T I C)$ and flourine concentrations do not display any large increases throughout the duration of the experiments.

A number of minor or trace phases have been located in scattered occurrences on several sample surfaces, or were identified as minor components in XRD patterns from specimens picked from the surface. Several amorphous grains were found, including Fe-rich phases on the tops of samples \#4 and \#\&; Si-rich phases on the tops of samples \#5, \#8, and the bottom of \#4; Ti-Si-Fe-Al precipitates on the top of sample \#5; and 
$\mathrm{Mg}-\mathrm{Si}-\mathrm{Fe}$ phases from the bottom of sample \#8. SEM/EDS examinations indicate the presence of $\mathrm{Al}-\mathrm{Si}-\mathrm{Ni}$ amorphous phases, and clay-like XRD patterns were obtained from specimens removed from samples \#1 and \#5. SEM/EDS and optical examinations also indicate the presence of fine-grained $\mathrm{Fe}$-oxide crystals on the bottom of sample \#4, and blue-colored U-Cu precipitates on the top and bottom of sample \#8. In addition, combined SEM/EDS and XRD analyses suggest the presence of trace amounts of rutile and talc on the top surface of sample \#8.

\section{DISCUSSION}

\subsection{Dissolution Process}

In natural oxidizing systems, $\mathrm{UO}_{2}$ progressively oxidizes to $\mathrm{UO}_{2.33}$ by incorporating oxygen in interstitial lattice sites (Johnson and Shoesmith, 1988). Oxidation beyond this stage requires crystallographic rearrangement from an isometric to an orthorhombic structure. $\mathrm{UO}_{2} .33$ is generally the most oxidized stage of uraninite found in contact with natural carbonate-bearing ground waters.

Reduced $U(U-I V)$ is highly insoluble, with measured solubilities ranging from $10^{-6}$ to $10^{-12} \mathrm{M}$ (Langmuir, 1978; 011ila, 1987; Parks and Pohl, 1988). Solubilities of the uranyl ion (U-VI) are potentially much higher, increasing by many orders of magnitude over those of the reduced species. Uranium solubilities measured in synthetic ground waters in contact with uraninite are generally $>10^{-6} \underline{M}$ (Johnson, 1982; Forsyth et al., 1986; 01lila, 1987; Wilson, 1987; Forsyth and Werme, 1987). Under oxidizing conditions, $\mathrm{UO}_{2+x}$ dissolves to form $\mathrm{UO}_{2}{ }^{2+}$ and associated hydrolysis products (Wang and Katayama, 1982; Johnson and Shoesmith, 1988). 
Ground water species, including halides, sulfates, phosphates, and carbonates, complex with uranyl ions and thus should enhance the solubility of $\mathrm{UO}_{2}$ (Langmuir, 1978; Thomas and Till, 1984).

Results from the present experiments indicate that there is very little release of $U$ during the initial 13 to 20 weeks of reaction (Table 2; Fig. 2). After 20 weeks, all experimental solutions show increased $U$ concentrations, probably indicating that dissolution of the oxidized uraninite has begun. This interpretation is strengthened by the appearance of $\mathrm{UOH}$ minerals on the sample surface at this time, since $U$ will not form hydrated oxides until it is fully oxidized to the U-VI state (Johnson and Shoesmith, 1988). The rapid onset of dissolution may reflect the high SA/V conditions under which the tests were run. Calculations indicate that uraninite exposed to air, in the presence of an aqueous surface film, will oxidize at a rate more than three orders of magnitude faster than uraninite submerged in oxygenated water (at $25^{\circ} \mathrm{C}$; Posey-Dowty et al., 1987). The high $S A / V$ conditions may also facilitate $U$ dissolution as the limited amounts of solution present will become rapidly saturated and precipitates will form only after a small amount of the $\mathrm{UO}_{2}$ surface has reacted. The precipitates then act as a "sink" for subsequently dissolved $U$, allowing rapid dissolution of the $\mathrm{UO}_{2}$ surface. Similar accelerated reactions under low SA/V conditions have been previously observed with glass alteration (Ebert et al, 1991).

Most experiments display a transient period of decreased uranium release between 33 to 46 weeks. This decrease may occur as UOH minerals begin to precipitate and lower $L$ solution concentrations relative to what they previously were in the presence of the $\mathrm{UO}_{2+x}$ surface alone. 
Alternatively, this decrease may result from the formation of a thin Mg-, $\mathrm{Si}-$, and $\mathrm{Al}$-rich surface film that reduces the dissolution rate of the $\mathrm{U0}_{2+x}$ matrix (Lahalle et al., 1988, 1989; Franco et al., 1989; Trocellier et al., 1990; Wilson and Gray, 1990). Preliminary studies of exposed $\mathrm{VO}_{2+x}$ surfaces in this study also have identified localized enrichments of Si, $\mathrm{Mg}$, and Al. XRD spectra from sample \#8 also indicate the presence of trace amounts of talc $\left[\mathrm{Mg}_{3} \mathrm{Si}_{4} \mathrm{O}_{10} \mathrm{O}(\mathrm{OH})_{2}\right]$. These examinations, however, indicate that this layer is a relatively minor characteristic of the overall reaction surface, and thus probably will not be sufficiently developed to offer a protective cover to $\mathrm{UO}_{2+x}$ dissolution.

The transient period of decreased $U$ release is followed by a period of rapid-pulsed release that starts after approximately one year and subsides after 1.5 to 2 years of testing (Table 2, Fig. 2). After two years, release levels decline to an apparent "steady-state" that has continued up to the present 4.5 years of reaction. The surfaces of samples terminated after the pulse release have a new sequence of mineral phases, where the previously dominant $\mathrm{UOH}$ minerals have been replaced by uranyl silicate phases such as uranophane and boltwoodite.

Due to the relatively low solution concentrations of $U$ and the low total volumes of water used in the experiments, only a minor fraction of the total release component can be attributed to release by a soluble uranium species. For example, the $\langle 5$ to $10 \mathrm{ppm} U$ concentrations expected in $\sim 25^{\circ} \mathrm{C}$ ground water solutions contacting uraninite or schoepite (Gayer and Leider, 1955; Johnson, 1982; Oversby and Wilson, 1985; Kertes and Guillaumont, 1985), combined with the $1.40 \mathrm{~mL}$ of total solution recovered from experiment \#1 during the pulse release period (between 45.6 and 
52 weeks) would account for $<0.5 \%$ of the tuta? $U$ released. Although the $90^{\circ} \mathrm{C}$ solutions used in the present experiment; may have slightly higher solubilities for $U$ (Kertes and Guillaumont, 1985), the amount of $U$ released via soluble species transport would still only account for a small fraction of the total release.

The potential coniribution of soluble $U$ to the total release fraction at the $90^{\circ} \mathrm{C}$ test conditions is difficult to evaluate due to a scarcity of experimental data. Garisto and Garisto (1986) note that $U$ concentrations may increase in the $\mathrm{UO}_{2}$-water system, while decreasing in the $\mathrm{UO}_{2}$-carbonate-water and $\mathrm{UO}_{2}$-phosphate-water systems between 25 and $100^{\circ} \mathrm{C}$. These temperature-induced differences may reflect the destabilization of uranyl carbonate and phosphate complexes with respect to $U$ hydrolysis products at higher temperatures (Paquette and Lemire, 1981).

Release of soluble $U$ from the samples may be aided by a wicking process, whereby a thin film of surface water forms a continuous bridge connecting the $\mathrm{UO}_{2+x}$ surface, TeflonTM stand, and accumulated liquid in contact with the stainless steel vessel. This scenario could conceivably result in a concentration gradient, whereby $U$ is leached from the pellets,

diffuses through the water film, and finally reprecipitates on the TeflonTM stand or bottom of the sample chamber. While wicking may provide an explanation for the large concentrations of $U$ released with these experiments, it does not rationalize either the initial onset nor the termination of the pulsed release interval.

The $U$ release pattern may be dependent on the sequence of mineral precipitates forming on the sample surface. For example, dissolution of the $\mathrm{UO}_{2}$ matrix and the formation of $\mathrm{UOH}$ minerals may result in release of 
uranium becalise $\mathrm{UOH}$ phases have relatively large solubility products in ground water. By contrast, the uranyl silicate phases that form have much lower solubility products for $U$. Evidence for this effect is provided by dissolution pits on the surfaces of $\mathrm{UOH}$ minerals that exhibit a close spatial relationship with uranyl silicate phases. This association suggests that the uranyl silicate phases may have lowered solution concentrations of $U$ to a point where $\mathrm{UOH}$ phases were dissolving.

The observed temporal correlation between the formation of various secondary phases, changes in the $U$ release rates, and leachate cation depletion trends all point to a strong cause and effect relationship between the precipitation of secondary uranyl silicates and decreased $U$ release rates. Solubility constraints, however, still limit the total amount of uranium that can be released via solution. Furthermore, solutions that migrate down the sample sides and drip from the bottom would be in contact mostly with the $\mathrm{UO}_{2+x}$ surface and $\mathrm{UOH}$ minerals. Uranophane and boltwoodite are entirely absent from these lower sample surfaces, whereas soddyite occurs only in trace amounts. Thus, any depletion of uranium occurring in the presence of less soluble phases on the tor surface, would be counterbalanced by increases while in contact with more sciuble phases located on the side and bottom surfaces.

Experiments terminated during the pulsed-release interval are characterized by an abundance of fine particulate matter across the sample surfaces and TeflonTM stands (Fig. 6a). The particles are thought to originate during surface disintegration and subsequent spallation of solids as the $\mathrm{UO}_{2}$ intergrain boundaries are weakened by corrosion. SEM examinations provide strong evidence for such a phenomenon in highly 
corroded intergrain boundary regions and the appearance of surface craters produced as overlying $\mathrm{UO}_{2}$ granules were loosened and washed from the samples (Figs. $4 \mathrm{~b}$ and $4 \mathrm{c}$ ). The particles are also concentrated on samples terminated during the pulsed release interval, while they are rare on samples terminated after the $U$ pulse had subsided. These relationships suggest that $\mathrm{UO}_{2}$ particulates are responsible for the the large pulse of $U$ release from the sample between one and two years. It is important to note, however, that spallation of particles is not the underlying cause of the pulsed release, but rather appears to be a symptom resulting from the rapid dissolution of grain boundaries.

The release of $U$ in particulate matter may also help to explain the large variations in total $U$ release between differant experiments (Table 2, Fig. 2). It is postulated that for samples where water flow across the surface was relatively unrestricted, the pellet surfaces were easily flushed of any loosened particulate matter. Where water flow was partially restricted, either by growth of mineral phases, sample orientation, and/or evaporative processes, there tended to be only moderate removal of particulate matter from the surfaces.

The end of pulsed release period coincides with precipitation of uranyl silicates on the sample surfaces. These new phases may bring about an end to the pulse interval by a combination of several processes. First, dense mats of uranophane and boltwoodite needles may provide filtration systems that strain particulate matter from solutions migrating across the samples. Particulates that are trapped in this manner will now contribute to uranium release only by dissolving, rather than being quickly washed from the surface. Secondly, lower uranium solubilities in the presence of 
uranyl silicates, may reduce the driving force for dissolution of the intergrain boundary regions. Samples terminated after the pulsed-release period display more uniformly corroded $\mathrm{UO}_{2+x}$ surfaces, quite distinct from the irregular surfaces that characterize earlier samples (for example, compare Figs. 4b with $4 d$ ). Finally, the mat of secondary minerals may form a cohesive blanket that prevents further dislodging of $\mathrm{UO}_{2}$ granules. It is important to note that this blanket does not appear to protect the surface from leaching, as SEM examinations reveal that the leachant solution has had continued access to the $\mathrm{UO}_{2+x}$ surface, even in areas where dense mats of crystais have grown (Figs. $6 a, 6 e, 6 h, 6 i$, and $6 j$ ).

\subsection{Mineral Paragenesis}

The top surfaces of all samples display circular accumulations of minerals where water drops have contacted the sample and spread out across the surface (Figs. $3 a$ and $3 b$ ). These patterns are best developed on samples \#1 and \#5, where extensive mats of uranyl silicate phases have formed. Mineral zonation on these samples is not only expressed in differing accumulation densities of minerals, but also in the spatial distribution of various types of mineral phases to each other. This zonal distribution probably reflects variable precipitation rates of the different phases under the influence of semi-restrictive water flow patterns.

Detailed examination of the sample surfaces has revealed a mineral paragenetic relationship where uraninite pellets are initially altered to UOH minerals, followed closely by soddyite, and finally alkali and alkaline earth bearing uranyl silicates (Fig. 7). Dehydrated schoepite is the 
dominant $\mathrm{UOH}$ mineral phase present, a finding in agreement with that of Vochten et al. (1990), who identified dehydrated schoepite as the characteristic phase forming at temperatures of $100^{\circ} \mathrm{C}$. Soddyite replaces dehydrated schoepite in some locations, while elsewhere it precipitates directly on the $\mathrm{UO}_{2+x}$ surface.

The top surfaces of samples terminated after 2.5 years are nearly devoid of schoepite and dehydrated schoepite. It is likely that these phases were initially present on the surface, but subsequently have been replaced by a more stable mineral assemblage. The central portions of the top surfaces of these samples are now dominated by uranophane and becquerelite. Soddyite, boltwoodite, and compreignacite also occur, but are less abundant, and are restricted to the outer margins of the top surfaces. Schoepite, dehydrated schoepite, and soddyite also occur on the side and bottom surfaces of these samples. Precipitation of becquerelite generaliy appears to precede that of uranophane, except for a few isolated occurrences where the two phases are coprecipitated. Most becquerelite also displays extensive corrosion pit development, and in many instances uranophane can clearly be seen to have precipitated within inese dissolution features (Fig. 6e). Where boltwoodite and uranophane occur together, boltwoodite always overlies uranophane, suggesting that it precipitated later. Compreignacite, boltwoodite, soddyite, and schoepite often display complex crystal intergrowths, indicating coprecipitation of these phases.

The paragenetic trends previously described bear a remarkable similarity to sequences observed for oxidized zones in natural uranium occurrences. For example, Frondel (1956) identified an oxidative 
alteration sequence for uraninite occurring in pegmatites, where an inner core of primary mineralization is surrounded by a middle layer of $\mathrm{UOH}$ minerals, followed by an outer layer of uranyl silicates (uranophane, soddyite, sklodowskite, and kasolite $\left.\left[\mathrm{Pb}\left(\mathrm{UO}_{2}\right)\left(\mathrm{SiO}_{3}\right)(\mathrm{OH})_{2}\right]\right)$. Finch and Ewing (1989) identified an alteration sequence where $\mathrm{UOH}$ minerals have been replaced by the uranyl silicates uranophane and cuprosklodowskite $\left[\left(\mathrm{H}_{3} \mathrm{O}\right)_{2} \mathrm{Cu}\left(\mathrm{UO}_{2}\right)_{2}\left(\mathrm{SiO}_{4}\right)_{2} \bullet 4 \mathrm{H}_{2} \mathrm{O}\right]$. Any mineralogic differences between these two natural alteration sequences and the present experiments can be attributed to the presence of radiogenic $\mathrm{Pb}$ and the close spatial association of $\mathrm{Cu}$ mineralization to deposits in the latter study. Other investigations suggest that schoepite may be the solubility limiting phase for $U$, and thus, the phase that ultimately will regulate the dissolution rate of spent fuel; Bruno and Sandino, 1989; Wilson, 1990; Choppin, 1990). Computer-based alteration models indicate that schoepite will be the final phase that forms, following the precipitation first of haiweeite $\left[\mathrm{Ca}\left(\mathrm{UO}_{2}\right)_{2} \mathrm{Si}_{6} \mathrm{O}_{15} \cdot 5 \mathrm{H}_{2} \mathrm{O}\right]$ and/or uranophane, followed by soddyite (Bruton and Shaw, 1987). These interpretations directly conflict the results obtained in this study, as well as sequences observed in natural uraninite occurrences. These simulations were run as closed system tests, with exhaustion of limited amounts of first $\mathrm{Ca}$ and then Si lenting to the precipitation of soddyite and schoepite, respectively. The difference between the experimental and modeled results may also attest to the importance of mineral kinetics in controlling the complex alteration sequence of uraninite. As Bruton and Shaw (1987) noted in their study, kinetic inhibitions to phase precipitation were not included in their models due to a lack of an adequate data base. With the present 
experimental results, dehydrated schoepite is the initially dominant phase to be precipitated, even though uranyl silicates may be the more thermodynamically stable phases.

Experiments identifying schoepite as the long-term solubility limiting solid phase may not have been run of a long enough duration to obtain a stable mineral assemblage for the alteration of uraninite or were run with concentrations of alkalis and $\mathrm{Si}$ that were exhausted during the test period. Both the oxidation of $\mathrm{UO}_{2}$ and the rate of saturation of the leachate solution with respect to particular secondary uranyl phases should be accelerated in the presence of the high $S A / V$ test conditions used in these experiments. The UTM should thus result in a secondary phase formation rate that is accelerated relative to experiments conducted under saturated water conditions.

Wilson (1990) has identified uranophane, haiweeite, and possibly soddyite in filtered residues from rinse solutions reacted for as little of 0.5 years. These tests were run at $85^{\circ} \mathrm{C}$ in stainless steel containers, with spent nuclear fuel samples immersed in J-13 well water. Although this mineral assemblage is similar to that found in the present study, the UTM has identified uranyl silicates only after 3.5 years of reaction. The cause of this discrepancy is, as of yet, undetermined.

The Wilson (1990) tests differ from the present experiments mainly in their lower SA/V ratios, the use of radioactive fuel, and minor variations in leachant composition. The lower SA/V ratios of the saturated tests should inhibit the formation of secondary phases, due to the diluting effects of large leachant volumes. This should delay the formation of uranyl silicates, a pattern opposite to what is observed. Differences may 
also be related to increased radiolysis effects of the saturated test solutions, but again, the decreased SA/V ratios should dilute any radiolysis produced species. The Wilson (1990) study utilizes a leachant with slightly enriched in $\mathrm{Ca}$ and $\mathrm{Mg}$, and slightly depleted $\mathrm{Si}$ and $\mathrm{Al}$ concentrations. Whether or not these variations have any effect on the observed mineralogic sequence may require additional testing.

\subsection{Secondary Phase Dissolution}

Each pits and hollow crystal coatings that formed on dehydrated schoepite and becquerelite crystals provide evidence for the occurrence of $\mathrm{UOH}$ mineral dissolution during the tests (Figs. 6c, 6e, and 6h). Several potential factors may independently or collectively result in the instability of these phases. These factors include (1) increase temperature, (2) spontaneous formation of dehydrated schoepite from schoepite, (3) decreasing $U$ solution concentrations, and (4) $\mathrm{pH}$ decreases.

Although temperature effects on secondary phase dissolution were not examined during these experiments, the importance of temperature in controlling the stability of certain minerals in an actual repository environment is of extreme importance in repository evaluations. Thermodynamic considerations indicate that the stability field of $\mathrm{UO}_{2}(\mathrm{OH})^{+}$and $\mathrm{UO}_{2}{ }^{+}$will expand rapidly under the influence of increasing temperature (Parquette and Lemire, 1981), at the expense of decreasing stability fields for schoepite, $\mathrm{UO}_{2}{ }^{2+}$ and $\mathrm{UO}_{2}(\mathrm{c})$.

Calculations based on thermodynamic data of Lemire and Tremaine (1980), and assuming a $\Sigma U$ activity of $10^{-6} \underline{M}$, indicate that the $25^{\circ} \mathrm{C}$ equilibrium boundary separating $\mathrm{UO}_{2}(\mathrm{OH})^{+}$and dehydrated schoepite is 
located at $\mathrm{pH}=5.0$, while the corresponding boundary separating $\mathrm{UO}_{2}(\mathrm{OH})^{+}$ and schoepite is at $\mathrm{pH}=5.3$. With an increase in temperature to $100^{\circ} \mathrm{C}$, the corresponding equilibrium boundaries will switch their respective positions. At this temperature, the dehydrated schoepite- $\mathrm{UO}_{2}(\mathrm{OH})^{+}$ boundary is located at $\mathrm{pH}=5.7$, while the schoepite $-\mathrm{UO}_{2}(\mathrm{OH})^{+}$boundary is located at $\mathrm{pH}=5.5$. These trends illustrate that the stability fields for both schoepite and dehydrated schoepite can be expected to decrease with increasing repository temperatures and that dehydrated schoepite may be stable under a wider range of conditions at higher temperatures. It should be cautioned, however, that while temperature appears to have a direct role in influencing the stability of secondary phases, its overall effect on phase dissolution is difficult to evaluate due to possible destabilization of uranyl di- and tri-carbonate uranyl species at higher temperatures (Parquette and Lemire, 1981).

Dissolution of $\mathrm{UOH}$ phases may also occur when $U$ concentrations decrease in solutions in contact with the secondary phases. Reduced concentrations may, in turn, result from the precipitation of uranyl silicate phases such as uranophane and boltwoodite that have lower solubility products for U relative to UOH phases (Bruton and Shaw, 1987).

The previously mentioned equilibrium boundary changes may also have an influence on the stability of UOH phases under experimental cuiditions. Dehydration of schoepite and the formation of dehydrated schoepite will result in a shift in the equilibrium boundary between $\mathrm{UO}_{2}(\mathrm{OH})^{+}$and the solid $\mathrm{UOH}$ phase from a $\mathrm{pH}$ of 5.5 to 5.7 (at $\left[\mathrm{U}\right.$ activity of $10^{-6} \mathrm{M}$ ). This 
change will occur while solutions reacting with the $\mathrm{UOH}$ phases are becoming increasingly acidic. Although results from the present study and those of Bruton and Shaw (1987) indicate a maximum $\mathrm{pH}$ decrease to $\sim 6.5$, the results are still of interest because the equilibrium boundary position is moving in a direction opposite to that of the leachate.

$\mathrm{pH}$ decreases may result from several processes including carbonate complexation of $U$ (Eqs. $1 a$ and $1 b$ ).

$$
\begin{aligned}
& 2 \mathrm{HCO}_{3}{ }^{-}+\mathrm{UO}_{2}(\mathrm{~s}) \longleftrightarrow \mathrm{UO}_{2}\left(\mathrm{CO}_{3}\right)_{2}{ }^{2-}+2 \mathrm{H}^{+} \\
& 3 \mathrm{HCO}_{3}^{-}+\mathrm{UO}_{2}(\mathrm{~s}) \leftrightarrow \mathrm{UO}_{2}\left(\mathrm{CO}_{3}\right)_{3}^{4-}+3 \mathrm{H}^{+}
\end{aligned}
$$

These reactions may also explain the decreasing $\mathrm{HCO}_{3}-$ concentrations noted in solution (Table 1); however, the low concentration of $U$ in solution (Table 2), suggests that this reaction may only account for $\sim 10 \%$ of the observed $\mathrm{HCO}_{3}$ - decrease.

A second process that will reduce the $\mathrm{pH}$ and $\mathrm{HCO}_{3}-$ concentration is the transformation of bicarbonate into formic and oxalic acids. Solution analyses indicate that inorganic carbon is being converted into organic carbon, whereas total carbon concentrations remain constant (Table 2). The detection of $\mathrm{CHO}_{2}^{-}(9-19 \mathrm{mg} / \mathrm{L})$ and $\mathrm{C}_{2} \mathrm{O}_{4}{ }^{2-}(2-4 \mathrm{mg} / \mathrm{L})$ in the leachate solution supports this position. The underlying mechanism for this conversion may involve a-radiolysis effects from the $\mathrm{UO}_{2}$ samples. Formic 
and oxalic acids have been produced in experiments with water condensed on alpha-producing ${ }^{241}$ Am foils (Wronkiewicz et al., 1991b). Organic species may also play an important role in actinide complexation and migration.

A final process that may lower the $\mathrm{pH}$ of solutions involvas the radiolytic decomposition of molecular nitrogen, and a several-step recombination process of atomic nitrogen with oxygen, water, and associated radiolytic products to produce nitrogen acids (Burns et al., 1982). This process has been observed in experiments where air and water systems have been exposed to either alpha or gamma irradiation (Wronkiewicz et al., 1991b). Although $\mathrm{pH}$ decreases resulting from this process may be minor in the relatively low radiation fields produced by $\mathrm{UO}_{2}$ in the present tests, the abundance of fission products and actinides in spent nuclear fuel would result in a radiation field several orders of magnitude greater than that of $\mathrm{UO}_{2}$, and thus would lead to conditions where nitrogen acid generation would become enhanced in an actual repository scenario.

\subsection{Surface Area of Sample vs. Leach Rate}

The experimental matrix was designed to test the effects of surface area on $U$ leach rates. Results demonstrate that the surface configuration does not have any measurable effect on the uranium release to solution under low water volume conditions. In fact, the variability observed between duplicate samples often exceeds the variation noted between different sample configurations. As previously discussed, most of this variation is believed to arise from the release of particulate matter from the sample surface. 
Empirical observations of samples, combined with analytical results from leachate solutions, indicate that the mannerism in which the injected water contacts and spreads out across the sample surface may have a more critical role in influencing the reaction. Samples with random distribu.tions of secondary phases, indicating that water flow was relatively unrestricted across the surface, typically have the largest $U$ releases. Samples with circular halos of precipitants that suggest water flow was partially restricted, have lower overall release rates. Thus, total release from the sample may depend upon the way in which water contacts the surface, and the influence that water flow has on both the formation of secondary precipitates and disintegration of the sample surface.

\subsection{Implications for Spent Fuel Disposal and Future Research}

Although experiments conducted with $\mathrm{UO}_{2}$ may not be entirely representative of reactions expected from spent fuel, the experiments may provide insights into the potential behavior of spent fuel dissolution since spent fuel is composed dominantly of $U$. The present experiments indicate that $\mathrm{UO}_{2}$ dissolution in a moist oxidizing environment will be controlled by a complex interaction of a number of processes including dissolution rates of grain boundaries, spallation of surface particles, secondary phase formation and stability, and mode of contact of water with the waste form.

Many of the more soluble radionuclides that reside in the grain boundary regions (for example, ${ }^{137} \mathrm{Cs}$ and $90 \mathrm{Sr}$ ) are readily mobilized during saturated dissolution tests with spent fuel (Johnson and Shoesmith, 1988). The rapid disintegration of intergrain boundaries noted in the present 
experiments, indicate that soluble intergrain nuclides may also be readily mobilized in an unsaturated repository environment. Furthermore, the spallation of $\mathrm{UO}_{2+x}$ granules from the sample surfaces may also continuously expose new grain boundaries to corrosive fluids, thereby prolonging the rapid release period for grain boundary elements.

The resultant pulsed-release of uranium associated with spallation of $\mathrm{UO}_{2+x}$ granules also has implications for the release of radionuclides from the $\mathrm{UO}_{2}$ matrix of spent fuel. Since the amount of $U$ released in the experiments appears to be largely controlled by the migration of the finegrained particulate matter, it follows that the migration of other radionuclides contained in the $\mathrm{UO}_{2}$ matrix of spent fuel may also be controlled by particulate dispersion. The mobility of activated species such as $\mathrm{Pu}$ and Am may potentially be much higher with particulate dispersion than if transport was controlled by solubility of the $\mathrm{UO}_{2}$ matrix or the individual radionuclides alone. Migration of these species may now be controlled by the ability of the repository hydrologic system to transport fine solids from the waste package environment. Filtered solution analyses, from both $\mathrm{UO}_{2}$ and spent fuel tests utilizing the UTM, will be required to quantify this release mechanism.

The similarity of secondary mineral assemblages developed in both the unsaturated tests and weathered uraninite occurrences emphasizes the importance of solution composition in determining which phases will form. Therafore, the ground water composition (and the influence of degrading engineered barrier systems in altering this composition) will play a critical role in determining which secondary minerals will form during spent fuel alteration. Dissoluiion of some $\mathrm{UOH}$ minerals indicates that 
radionuclides contained in these metastable phases may readily be mobilized under thr influence of minor environmental changes. Uranyl silicates (or possibly uranyl vanadates or phosphates; Hostetler and Garrels, 1962; Langmuir, 1978) should influence the rate at which some nuclides are eventually released from the waste form and its associated alteration products into the near-field environment. Research into the partitioning of trace elements into alteration phases is required if these minerals are to be included as barriers to radionuclide migration.

\section{CONCLUSIONS}

A set of experiments have been in operation for 4.5 years, where $\mathrm{UO}_{2}$ pellets encased in Zircaloy cladding are contacted by an intermittent flow of dripping groundwater. The tests are conducted under atmospheric conditions, at $\sim 90^{\circ} \mathrm{C}$, in a test environment that simulates the unsaturated water conditions expected in the proposed Yucca Mountain nuclear waste repository. Samples first begin to react after 13 to 20 weeks, as indicated by the formation of secondary alteration minerals and notable increases in $U$ release to solution. This change is interpreted to reflect the onset of oxidative dissolution of the $\mathrm{UO}_{2}$ surface and the formation of dehydrated schoepite (and possibly other $\mathrm{UOH}$ minerals).

After appruximately one year, samples display a sharp increase in $U$ release. This rapid pulsed-release is the most conspicuous feature of the entire 4.5-year reaction sequence. Samples surfaces are now partially covered by dehydrated schoepite crystals, as well as minor schoepite, soddyite, and $\mathrm{Fe}$-oxides. The $\mathrm{UO}_{2+x}$ surfaces also show evidence for 
extensive intergranular corrosion and most of the sample is covered with fine particulate matter, apparently produced from dislodged surface granules.

After 1.5 to 2.0 years of reaction, the rapid pulsed-release of $U$ subsides, and release rates decline to an apparent steady-state level that has continued up to the present 4.5 years. The top sample surfaces are now covered by uranyl silicate phases (uranophane, boltwoodite, and sklodowskite) that have incorporated cations from the EJ-13 water, as well as uranium from the dissolution of the $\mathrm{UO}_{2+x}$ surfaces and/or previously deposited minerals. The similar mineralogy observed between the unsaturated tests and those of natural uraninite occurrences exposed to surficial weathering suggests that these experiments have formed a longterm alteration sequence of uranyl silicates that may be expected to control spent fuel dissolution in the proposed repository. Both the dissolution of the $\mathrm{UO}_{2+x}$ surface and the quantity of loosened fine-grained particulates on the sample surface appears to have declined while uranyl silicates are precipitating.

Only $5 \%$ of the total uranium released from the samples occurs in solution or as suspended fine particulate matter. The remainder either settles to the bottom of the vessel or is reprecipitated on the surfaces of test components. Rapid dissolution of the $\mathrm{UO}_{2}$ pellets, combined with spallation of particulates from the sample surface, may have important implications for the overall performance of spent fuel in the waste repository. In particular, release rates for radionuclides contained in the $\mathrm{UO}_{2}$ matrix may not be limited by $U$ solubility if waste form degradation and dispersion is controlled by spallation of particulate matter from spent fuel. 


\section{ACKNOWLEDGMENTS}

We wish to thank D. N. Washburn of DuPont Company for providing an FTIR spectrum and for identification of TeflonTM deposits. This work was supported by the U.S. Department of Energy, Office of Civilian Radioactive Waste Management, Yucca Mountain Project under subcontract to Lawrence Livermore National Laboratory, SANL 910-007. Access to unpublished data of R. Finch is greatly appreciated. This manuscript has been greatly improved from critical reviews by C. J. Bruton and W. F. McKenzie. 


\section{REFERENCES}

Anderson, J. S., Roberts, L. E. J. and Harper, E. A., 1955. The oxides of uranium part VII. The oxidation of uranium dioxide. J. Chem. Soc., 3946-3959.

Bates, J. K. and Gerding, T. J., 1985. NNWSI phase II materials interaction test procedure and preliminary results. Argonne National Laboratory report ANL-84-81, $46 \mathrm{pp}$.

Bates, J. K. and Gerding, T. J., 1990. Application of the NNWSI unsaturated test method to actinide-doped SRL 165 type glass. Argonne National Laboratory report ANL-89/24, 8j pp.

Bruno, J. and Sandino, A., 1989. The solubility of amorphous and crystalline schoepite in neutral to alkaline aqueous solutions. In: W. Lutze and R. C. Ewing (Editors), Scientific Basis for Nuclear Waste Management XII, vol. 127, Materials Research Society, Pittsburgh, PA, pp. 871-878.

Bruton, C. J. and Shaw, H. F., 1987. Geochemical simulation of reaction between spent fuel waste form and $\mathrm{J}-13$ water at $25^{\circ} \mathrm{C}$ and $90^{\circ} \mathrm{C}$. In: M. J. Apted and R. E. Westerman (Editors), Scientific Basis for Nuclear Waste Management XI, vol. 112, Materials Research Society, Pittsburgh, $P A$, pp. 485-494.

Burns, W. G., Hughes, A. E., Marples, J. A. C., Nelson, R. S., and Stoneham, A. M., 1982. Effects of radiation on the leach rates of vitrified radioactive waste. J. Nucl. Mater., 107:245-270.

Choppin, G. R., 1990. Actinide speciation in spent fuel leaching studies. In: V. M. Oversby and P. W. Brown (Editors), Scientific Basis for Nuclear Waste Management XIII, vo1. 176, Materials Research Society, Pittsburgh, PA, pp. 449-456.

Christ, C. L. and CLark, J. R., 1960. Crystal chemical studies of some uranyl oxide hydrates. Amer. Mineral., 45:1026-1061.

Ebert, W. L., Bates, J. K., and Bourcier, W. L., 1991. The hydration of borosilicate waste glass in liquid water and steam at $200^{\circ} \mathrm{C}$. Waste Management (in press).

Finch, R. J. and Ewing, R. C., 1989. Alteration of natural $\mathrm{UO}_{2}$ under oxidizing conditions from Shinkolobwe, Katanga, Zaire: A natural analogue for the corrosion of spent fuel. SKB Technical Report 89-37, $27 \mathrm{pp}$.

Forsyth, R. S., Werme, L. O. and Bruno, J., 1986. The corrosion of spent $\mathrm{UO}_{2}$ fuel in synthetic groundwater. J. Nucl. Mater., 138:1-15.

Forsyth, R. S. and Werme, L. O., 1987. Corrosion tests on spent PWR fuel in synthetic groundwater. SKB Technical Report 87-16, 38 pp. 
Franco, F., Trocellier, P. and Menes, F., 1989. U0 2 corrosion study in mineral water: A surface analysis approach. In: W. Lutze and R. C. Ewing (Editors), Scientific Basis for Nuclear Waste Management XII, vol. 127, Materials Research Society, Pittsburgh, PA, pp. 343-349.

Frondel, C., 1956. Mineral composition of gummite. Amer. Mineral., $41: 539-568$.

Garisto, N. C. and Garisto, F., 1986. The dissolution of $\mathrm{UO}_{2}$ : A thermodynamic approach. Nucl. and Chem. Waste Management, 6:203-211.

Gayer, K. H. and Leider, H., 1955. The solubility of uranium trioxide $\mathrm{UO}_{3} \cdot \mathrm{H}_{2} \mathrm{O}$, in solutions of sodium hydroxide and perchloric acid at $25^{\circ}$. J. Amer. Chem. Soc., 77:1448-1450.

Hostetler, P. B. and Garrels, R. M., 1962. Transportation and precipitation of uranium and vanadium at low temperatures, with special reference to sandstone-type uranium deposits. Econ. Geol., 57:137-167.

Johnson, L. H., 1982. The dissolution of irradiated $\mathrm{UO}_{2}$ fuel in groundwater. Atomic Energy of Canada Limited report AECL-6837, 41 pp.

Johnson, L. H. and Shoesmith, D. W., 1988. Spent Fuel. In: W. Lutze and R. C. Ewing (Editors), Radioactive Waste Forms for the Future. NorthHolland Physics Publishing, Amsterdam, pp. 635-698.

Kertes, A. S. and Guillaumont, R., 1985. Solubility of $\mathrm{UO}_{2}$. A comparative review. Nucl. and Chem. Waste Management, 5:215-219.

Lahalle, M. P., Franco, P., Trocellier, P., Krupa, J. C., Genet, M., Allen, G., and Holmes, N., 1988. Leaching of solid $\mathrm{VO}_{2}$ in Volvic mineral water. Comptes rendus des seances de l'Academie des Sciences, $307: 1163-1166$.

Lahalle, M. P., Krupa, J. C., Guillaumont, R., Genet, M., Allen, G., and Holmes, N. R., 1989. Surface analysis of $\mathrm{UO}_{2}$ leached in mineral water studied by $x$-ray photoelectron spectroscopy. In: $W$. Lutze and R. C. Ewing (Editors), Scientific Basis for Nuclear Waste Management XII, vol. 127, Materials Research Society, Pittsburgh, PA, pp. 351-356.

Langmuir, D., 1978. Uranium solution-mineral equilibria at low temperatures with applications to sedimentary ore deposits. Geochim. Cosmochim. Acta, 42:547-569.

Lemire, R. J. and Tremaine, P. R., 1980. Uranium and plutonium equilibria in aqueous solutions to $200^{\circ} \mathrm{C}$. J. Chem. Eng. Data, 25:361-370.

$011 i a, K_{.}, 1987$. Dissolution of unirradiated $\mathrm{UO}_{2}$ fuel pellets in groundwater. In: Third Finnish-German Seminar on Nuclear Waste Management 1986. Report PC A13/MFA01, pp. 108-120. 
Oversby, V. M. and Wilson, C. N., 1985. Derivation of a waste package source term for NNWSI from the results of laboratory experiments. In: L. 0. Werme (Editor), Scientific Basis for Nuclear Waste Management IX, vol. 50, Materials Research Society, Pittsburgh, PA, pp. 337-346.

Paquette, J. and Lemire, R. J., 1981. A description of the chemistry of aqueous solutions of uranium and plutonium to $200^{\circ} \mathrm{C}$ using potential-pH diagrams. Nucl. Sci. and Engineering, 79:26-48.

Parks, G. A. and Pohl, D. C., 1988. Hydrothermal solubility of uraninite. Geochim. Cosmochim. Acta, 52:863-876.

Peters, J. M., 1965. Caractere general des reactions d'echange chez certains composes uraniferes et son interpretation dans l'hypothese de H. Brasseur. Bull. Soc. Royale Sci. Liege, 34:656-688.

Posey-Dowty, J., Axtmann, E., Crerar, D., Borscik, M., Ronk, A., and Woods, W., 1987. Dissolution rate of uraninite and uranium roll-front ores. Econ. Geol., 82:184-194.

SCP (Site Characterization Plan), 1988. U.S. Department of Energy, Office of Civilian Radioactive Waste Management, DOE report DOE/RW-0199.

Smith, D. K., Jr., 1984. Uranium mineralogy. In: B. De Vivo, F. Ippolito, G. Capaldi, and P. R. Simpson (Editors), Uranium Geochemistry, Mineralogy, Geology, Exploration and Resources. Institute of Mining and Metallurgy, London, pp. 43-88.

Thomas, G. F. and Till, G., 1984. The dissolution of unirradiated $\mathrm{VO}_{2}$ fuel pellets under simulated disposal conditions. Nucl. and Chem. Waste Management, 5:141-147.

Tremaine, P. R., Chen, J. D., Wallace, G. J., and Boivin, W. A., 1981. Solubility of uranium(IV) oxide in alkaline aqueous solutions to $300^{\circ} \mathrm{C}$. J. Soln. Chem., 10:221-230.

Trocellier, P., Franco, P. and Menes, F., 1990. Etude des mecansimes de corrosion aqueuse du dioxyde d'uranium. Waste Management Research Abstracts, No. 19. Information on radioactive waste programmes in progress. International Atomic Energy Agency, Vienna, IAEA/WMRA/19.

Vochten, R., De Grave, E. and Lauwers, H., 1990. Transformation of synthetic $\mathrm{U}_{3} \mathrm{O}_{8}$ into different uranium oxide hydrates. Mineral and Petrol., 41:247-255.

Wang, R. and Katayama, Y. B., 1982. Dissolution mechanisms for $\mathrm{UO}_{2}$ and spent fuel. Nucl. and Chem. Waste Management, 3:83-90.

Wilson, C. N., 1987. Summary results from the series 2 and series 3 NNWSI bare fuel dissolution tests. In: M. J. Apted and R. E. Westerman (Editors), Scientific Basis for Nuclear Waste Management XI, vol. 112, Materials Resear.h Society, Pittsburgh, PA, Pp. 473-483. 
Wilson, C. N., 1990. Results from NNWSI Series 3 spent fuel dissolution tests. Pacific Northwest Laboratory DOE report PNL-7170.

Wilson, C. N. and Gray, W. J., 1990. Effects of water composition on the dissolution rate of $\mathrm{UO}_{2}$ under oxidizing conditions. In: High Level Radioactive Waste Management, Volume 2. American Nuclear Society, La Grange Park, IL, and American Society of Civil Engineers, New York, NY, pp. 1431-1436.

Wronkiewicz, D. J., Bates, J. K., Gerding, T. J., Veleckis, E., and Tani, B. S., 1991a. Leaching action of EJ-13 water on unirradiated $\mathrm{UO}_{2}$ surfaces under unsaturated conditions at $90^{\circ} \mathrm{C}$ : Interim report. Argonne National Laboratory report ANL-91/11, 65 pp.

Wronkiewicz, D. J., Young, J. E., and Bates, J. K., 1991b. Effects of alpha and gamma radiation on unsaturated repository environment. In: T. Abrajano, Jr. and L. H. Johnson (editors), Scientific Basis for Nuclear Waste Management XIV, vol. 112, Materials Research Society, Pittsburgh, PA, pp. 99-106. 
Table 1. Solution $U$, Carbon, Anion, and Cation Concentrations

\begin{tabular}{|c|c|c|c|c|c|c|c|c|c|c|c|c|c|c|c|c|c|c|c|c|}
\hline \multirow{2}{*}{$\begin{array}{l}\text { Somple } \\
\text { Number }\end{array}$} & \multirow{2}{*}{$\begin{array}{l}\text { Somple } \\
\text { Interwal } \\
\text { (whs.) }\end{array}$} & \multirow{2}{*}{ pH } & \multirow{2}{*}{$\begin{array}{c}\text { Solution } \\
U\end{array}$} & \multicolumn{5}{|c|}{ Corbon } & \multicolumn{5}{|c|}{ Anions } & \multicolumn{7}{|c|}{ Cotions } \\
\hline & & & & $T O C$ & TK & $\mathrm{HCO}_{-}$ & $\mathrm{CH} 2 \mathrm{O}=$ & $\mathrm{C} 2 \mathrm{H} 4 \mathrm{OA}=$ & $a_{-}$ & F- & $\mathrm{MO}_{-}$ & 103 & $\mathrm{SO}_{-}-$ & B & Li & Co & $\mathrm{Ng}$ & $K$ & $\mathrm{No}$ & 5 \\
\hline 1 & $\begin{array}{l}10.7 \\
156.6 \\
182.6\end{array}$ & $\begin{array}{l}7.3 \\
6.8\end{array}$ & 1.70 & $\begin{array}{l}27.0 \\
25.0\end{array}$ & $\begin{array}{l}32 \\
4.6\end{array}$ & $\begin{array}{l}16.3 \\
22.9\end{array}$ & & & 17 & 2.0 & & 19 & 39 & $\begin{array}{l}0.28 \\
<0.35 \\
<0.34\end{array}$ & $\begin{array}{l}0.06 \\
<0.12 \\
<0.11\end{array}$ & $\begin{array}{l}0.50 \\
0.54 \\
0.40\end{array}$ & $\begin{array}{l}0.21 \\
0.06 \\
0.12\end{array}$ & $\begin{array}{l}2.90 \\
<2.95 \\
<2.93\end{array}$ & $\begin{array}{l}55 \\
41 \\
41\end{array}$ & $\begin{array}{l}15 \\
21 \\
23\end{array}$ \\
\hline 2 & $\begin{array}{l}101.7 \\
156.6 \\
182.6 \\
210.6 \\
231.5\end{array}$ & $\begin{array}{l}7.0 \\
6.9 \\
7.6 \\
7.6\end{array}$ & $\begin{array}{l}2.30 \\
1.99 \\
2.95\end{array}$ & $\begin{array}{l}22.2 \\
25.4 \\
36.2\end{array}$ & $\begin{array}{c}4.2 \\
3.9 \\
259\end{array}$ & $\begin{array}{l}21.3 \\
19.3\end{array}$ & 9.2 & 2.3 & $\begin{array}{l}17 \\
21 \\
22\end{array}$ & $\begin{array}{l}2.0 \\
7.8 \\
5.9\end{array}$ & $\begin{array}{l}<0.3 \\
1.7\end{array}$ & $\begin{array}{l}18 \\
22 \\
23\end{array}$ & $\begin{array}{l}37 \\
46 \\
39\end{array}$ & $\begin{array}{l}0.24 \\
<0.23 \\
0.22 \\
2.45 \\
0.53\end{array}$ & $\begin{array}{l}0.07 \\
<0.08 \\
<0.08 \\
<0.18 \\
<0.09\end{array}$ & $\begin{array}{l}0.87 \\
0.72 \\
1.02 \\
2.06 \\
2.41\end{array}$ & $\begin{array}{l}0.24 \\
0.09 \\
0.11 \\
0.01 \\
0.04\end{array}$ & $\begin{array}{l}2.64 \\
<1.91 \\
<1.86 \\
<7.45 \\
7.74\end{array}$ & $\begin{array}{l}45 \\
31 \\
32 \\
75 \\
61\end{array}$ & $\begin{array}{l}17 \\
17 \\
17 \\
32 \\
26\end{array}$ \\
\hline 3 & $\begin{array}{l}104.7 \\
156.6 \\
182.6 \\
210.6 \\
237.6\end{array}$ & $\begin{array}{l}6.6 \\
6.3 \\
7.0 \\
6.9\end{array}$ & $\begin{array}{l}2.50 \\
2.50 \\
2.0 Q\end{array}$ & $\begin{array}{l}19.2 \\
24.9 \\
25.0\end{array}$ & $\begin{array}{c}3.5 \\
1.8 \\
12.8\end{array}$ & $\begin{array}{c}17.8 \\
9.1\end{array}$ & 85 & 2.5 & $\begin{array}{l}16 \\
30 \\
22\end{array}$ & $\begin{array}{l}<1.7 \\
6.6 \\
5.0\end{array}$ & $\begin{array}{l}<0.3 \\
1.2\end{array}$ & $\begin{array}{l}22 \\
30 \\
24\end{array}$ & $\begin{array}{l}37 \\
49 \\
43\end{array}$ & $\begin{array}{l}0.41 \\
<0.30 \\
0.26 \\
<0.79 \\
0.38\end{array}$ & $\begin{array}{l}0.24 \\
<0.10 \\
0.09 \\
0.14 \\
0.18\end{array}$ & $\begin{array}{l}0.66 \\
0.84 \\
0.77 \\
0.83 \\
0.43\end{array}$ & $\begin{array}{l}1.11 \\
0.35 \\
0.43 \\
0.24 \\
0.32\end{array}$ & $\begin{array}{l}2.05 \\
<255 \\
<1.99 \\
<4.28 \\
2.74\end{array}$ & $\begin{array}{l}52 \\
27 \\
28 \\
58 \\
59\end{array}$ & $\begin{array}{l}7.9 \\
7.6 \\
7.4 \\
20 \\
20\end{array}$ \\
\hline 5 & $\begin{array}{l}104.7 \\
156.6 \\
188.6\end{array}$ & $\begin{array}{l}6.7 \\
6.9\end{array}$ & 1.20 & 17.4 & 22 & 112 & & & 78 & $<B .4$ & & 161 & 187 & $\begin{array}{l}0.28 \\
<0.99 \\
3.77\end{array}$ & $\begin{array}{l}0.06 \\
<0.33 \\
<0.20\end{array}$ & $\begin{array}{c}0.18 \\
\text { ind } \\
1.07\end{array}$ & $\begin{array}{l}0.19 \\
<0.04 \\
0.29\end{array}$ & $\begin{array}{l}2.37 \\
<9.08 \\
10.5\end{array}$ & $\begin{array}{l}53 \\
19 \\
69\end{array}$ & $\begin{array}{l}14 \\
1.6 \\
9.2\end{array}$ \\
\hline 6 & $\begin{array}{l}104.7 \\
156.6 \\
182.6 \\
210.6 \\
237.6\end{array}$ & $\begin{array}{l}7.9 \\
6.5 \\
5.9 \\
7.0\end{array}$ & $\begin{array}{l}1.50 \\
13.9 \\
1.54\end{array}$ & $\begin{array}{l}20.1 \\
22.0\end{array}$ & $\begin{array}{l}7.0 \\
5.3\end{array}$ & $\begin{array}{l}35.6 \\
26.9\end{array}$ & 19 & 3.8 & $\begin{array}{l}15 \\
22 \\
26\end{array}$ & $\begin{array}{l}<1.7 \\
3.7 \\
4.5\end{array}$ & $\begin{array}{l}<0.3 \\
0.87\end{array}$ & $\begin{array}{l}22 \\
56 \\
39\end{array}$ & $\begin{array}{l}31 \\
55 \\
57\end{array}$ & $\begin{array}{l}0.32 \\
0.22 \\
0.23 \\
<1.99 \\
0.39\end{array}$ & $\begin{array}{l}0.06 \\
0.05 \\
<0.08 \\
<0.26 \\
0.10\end{array}$ & $\begin{array}{l}1.14 \\
0.01 \\
0.27 \\
2.33 \\
1.40\end{array}$ & $\begin{array}{l}0.20 \\
0.09 \\
0.03 \\
0.37 \\
\text { nd }\end{array}$ & $\begin{array}{l}283 \\
<0.75 \\
<1.92 \\
<10.7 \\
5.45\end{array}$ & $\begin{array}{l}52 \\
41 \\
30 \\
78 \\
49\end{array}$ & $\begin{array}{l}16 \\
16 \\
14 \\
8.8 \\
18\end{array}$ \\
\hline 7 & $\begin{array}{l}101.7 \\
156.6 \\
182.6 \\
210.6 \\
231.6\end{array}$ & 6.0 & $\begin{array}{l}3.73 \\
0.53\end{array}$ & 26.0 & 9.7 & & & & 31 & 5.4 & $<0.3$ & 29 & 41 & $\begin{array}{l}0.91 \\
<0.91 \\
<0.48 \\
1.51 \\
<0.82\end{array}$ & $\begin{array}{l}<0.29 \\
<0.31 \\
<0.16 \\
<0.14 \\
<0.28\end{array}$ & $\begin{array}{l}9.01 \\
1.97 \\
1.52 \\
1.09 \\
\text { nd }\end{array}$ & $\begin{array}{l}0.45 \\
0.15 \\
0.07 \\
0.04 \\
\text { nd }\end{array}$ & $\begin{array}{l}<12.1 \\
<7.10 \\
<3.59 \\
<5.88 \\
<6.07\end{array}$ & $\begin{array}{l}90 \\
66 \\
37 \\
47 \\
6.8\end{array}$ & $\begin{array}{l}8.1 \\
13 \\
6.3 \\
14 \\
\text { nd }\end{array}$ \\
\hline 8 & 104.7 & & & & & & & & & & & & & 5.86 & $<0.40$ & 5.64 & 0.66 & $<16.7$ & 83 & 13 \\
\hline$E J-13$ & & 82 & 0.0004 & 6.9 & 18.4 & 94 & & & 8.6 & 2.8 & $<0.5$ & 8.2 & 21 & 0.16 & 0.044 & 9.08 & 0.96 & 808 & 46.5 & 34.4 \\
\hline
\end{tabular}


Table 2. Total Uranium Release

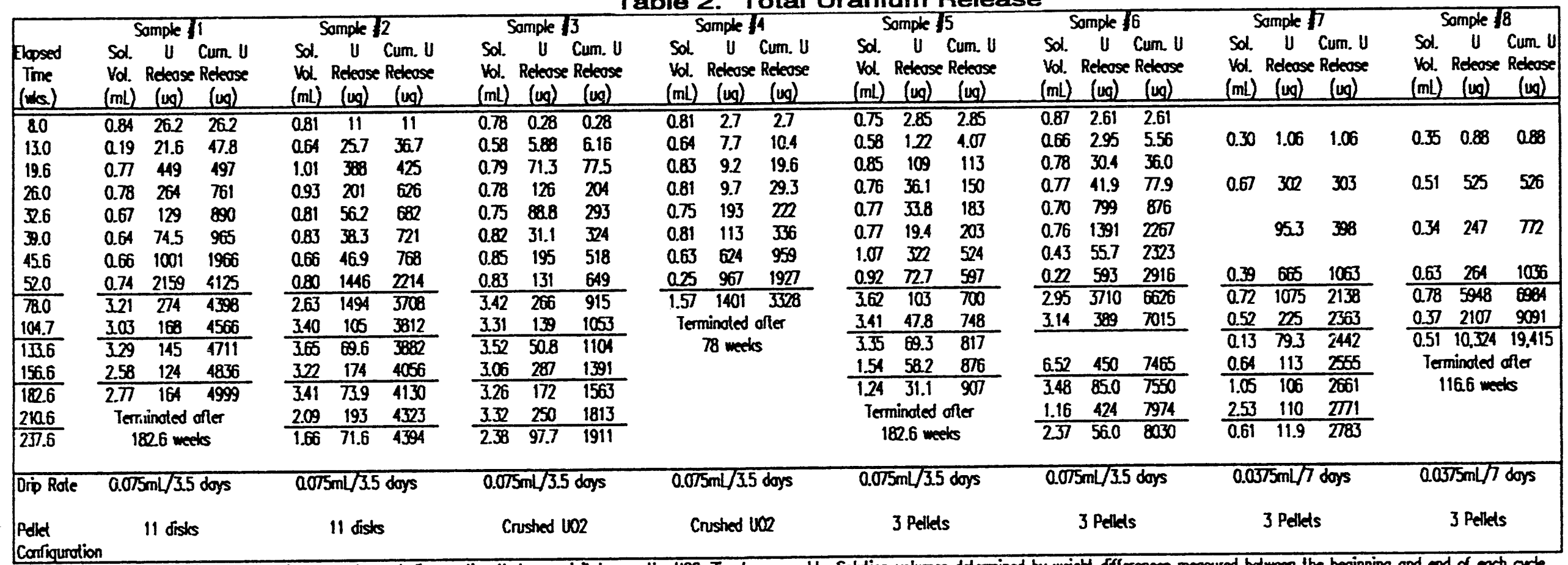

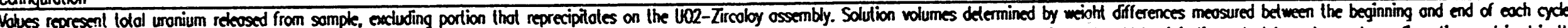

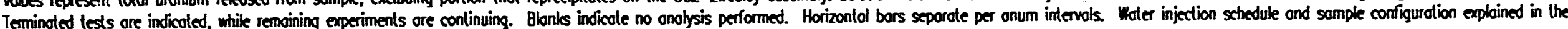
text All experiments were conducted of $90^{\circ} \mathrm{C}$. 
Table 3. Secondary Uranyl Phases Identified on Reacted $\mathrm{UO}_{2}$ Surfaces

\begin{tabular}{|c|c|c|}
\hline Schoepite & $\mathrm{UO}_{3} \cdot 2 \mathrm{H}_{2} \mathrm{O}$ & Dark yellow crystals \\
\hline Dehydrated Schoepite & $\mathrm{UO}_{3} \cdot 0.8 \mathrm{H}_{2} \mathrm{O}$ & $\begin{array}{l}\text { Yellow to green crystals "boat shaped" tabular } \\
\text { with single or rare double terminations }\end{array}$ \\
\hline Uranophane & $\mathrm{Ca}\left(\mathrm{UO}_{2}\right)_{2}\left(\mathrm{SiO}_{3} \mathrm{OH}\right)_{2} \cdot 5 \mathrm{H}_{2} \mathrm{O}$ & $\begin{array}{l}\text { Fine white needles--stellar groups of crystals } \\
\text { or continuous mats }\end{array}$ \\
\hline Boltwoodite & $\mathrm{K}\left(\mathrm{H}_{3} \mathrm{O}\right) \mathrm{UO}_{2}\left(\mathrm{SiO}_{4}\right) \cdot \mathrm{nH}_{2} \mathrm{O}$ & Fine yellow needles in continuous mats \\
\hline Soddyite & $\mathrm{U}_{5} \mathrm{Si}_{2} \mathrm{O}_{19} \cdot 6 \mathrm{H}_{2} \mathrm{O}$ & $\begin{array}{l}\text { Fine bladed crystals, drusy powders, or } \\
\text { coatings over previously deposited grains }\end{array}$ \\
\hline Becquerelite & $\mathrm{CaU}_{6} \mathrm{O}_{19} \cdot 10 \mathrm{H}_{2} \mathrm{O}$ & Dark yellow tabular crystals \\
\hline Compreignacite & $\mathrm{K}_{2} \mathrm{U}_{6} \mathrm{O}_{19} \cdot 11 \mathrm{H}_{2} \mathrm{O}$ & Yellow crystals, stacked pseudohexagonal plates \\
\hline Sklodowskite & $\mathrm{Mg}\left(\mathrm{UO}_{2}\right)_{2}\left(\mathrm{SiO}_{3} \mathrm{OH}\right)_{2} \cdot 5 \mathrm{H}_{2} \mathrm{O}$ & $\begin{array}{l}\text { Fine needles to elongated prims, minor in } \\
\text { occurrence }\end{array}$ \\
\hline
\end{tabular}


Table 40. X-Roy Diffraction Indexing Dato for Selected Mineral Phases Oblained from Somple Surfoces.

\begin{tabular}{|c|c|c|c|c|c|c|c|c|c|c|c|c|c|c|c|c|c|c|c|c|}
\hline \multicolumn{3}{|c|}{ Somple PUP8U-1B1 } & \multicolumn{3}{|c|}{ Somple PUP\&U-5 } & \multicolumn{3}{|c|}{ Sample PMPBU-101 } & \multicolumn{3}{|c|}{ Somple PIP\&I-1D2 } & \multicolumn{3}{|c|}{ Somple PMPQU-1E } & \multicolumn{3}{|c|}{ Sample PUPbU-1f } & \multicolumn{3}{|c|}{ Somple PMPdU-4A } \\
\hline da & 1 & Phose 10 & dA & 1 & Phase 10 & dA & 1 & Phose iD & $d A$ & 1 & Phose ID & da & 1 & Phose 1D & dA & 1 & Phose 10 & dA & 1 & Phose ID \\
\hline 7.47 & 100 & $\mathrm{~Bq} / \mathrm{Cm}$ & 7.39 & 100 & Sh & 7.93 & 30 & U & 7.93 & 60 & $U$ & 835 & $\overline{5}$ & Sk & 5.07 & 80 & DS & 625 & 100 & $S d$ \\
\hline 6.80 & 5 & Bo & $5 \pi 0$ & 5 & $\mathrm{Ba} / \mathrm{Cm}$ & 7.45 & $100 \mathrm{rsp}$ & $\mathrm{Cm} / \mathrm{Ba}$ & 7.45 & 40 & $\mathrm{Cm} / \mathrm{Bq}$ & 6.80 & 5 & Bo & 343 & 100 & DS & 5.07 & 50 & DS \\
\hline 5.90 & 1 & $?$ & 4.57 & 10 & $\mathrm{Cm}$ & 6.87 & 35 & Bo & 687 & 100 & Bo & 6.5 & 5 & Sk/Bo & 285 & 40 & DS & 4.83 & 25 & Sd \\
\hline 5.00 & 5 & OS & 370 & 60 & $\mathrm{Sh} / \mathrm{Cm}$ & 6.60 & 1 & $U / B q$ & 6.60 & 1 & $\mathrm{U} / \mathrm{Bq}$ & 5.90 & 10 & S & 2.56 & 25 & DS & 4.65 & 10 & Sd \\
\hline 4.45 & 100 & Bq? & 3.66 & 15 & Bq & 640 & 10 & Bo & 6.40 & 35 & Bo & 4.90 & 100 & Sk & 248 & 40 & DS & 4.55 & 100 & Sd \\
\hline 4.15 & 25 & Greose & 3.59 & 60 & $\mathrm{Sh} / \mathrm{Cm}$ & $6 \infty 0$ & 1 & $\mathrm{~cm}$ & $6 . \infty$ & 1 & $\mathrm{Cm}$ & 4.52 & 5 & $\$$ & 2.15 & 15 & DS & 4.15 & 10 & Greose \\
\hline 398 & 1 & $?$ & 351 & 50 & $\mathrm{Sh} / \mathrm{Bq} / \mathrm{Cm}$ & 5.42 & 25 & U/Bo & 542 & 30 & U/Bo & 4.32 & 5 & SK/BO & 2.03 & 20 & DS & 378 & 10 & Sd \\
\hline 380 & 100 & Greose & 3.37 & 15 & $\mathrm{~Bq} / \mathrm{Cm}$ & 4.80 & 30 & $u$ & 4.80 & 40 & $U$ & 4.18 & 30 & $S x$ & 1.99 & 50 & OS & 3.44 & 50 & DS \\
\hline 370 & 100 & $\mathrm{~cm}$ & 323 & 60 & $\mathrm{Sh} / \mathrm{Cm} / \mathrm{Bq}$ & 4.30 & 10 & $U / 80$ & 4.30 & 15 & U/BO & 4.08 & 10 & Sk & 1.82 & 20 & DS & 334 & 70 & Sd \\
\hline 350 & $20 s p$ & $\mathrm{~cm}$ & 3.16 & 6 & $\mathrm{Sh} / \mathrm{Bq}$ & 4.17 & 30 & Bo & 4.17 & 5 & Bo & 351 & 5 & $5 \times / B O$ & 1.78 & 35 & DS & 3.26 & 20 & Sd \\
\hline 3.42 & $15 s p$ & $B Q / O S$ & 303 & 15 & $\mathrm{Sh} / \mathrm{Cm}$ & 3.91 & 25 & $U / B O$ & 394 & 30 & $\mathbf{U}$ & 3.25 & 1 & sk & 1.64 & 5 & DS & 3.16 & 40 & $?$ \\
\hline 3.5 & $5 S p$ & $\mathrm{~B} / \mathrm{Cm}$ & 2.88 & 15 & $\mathrm{~Bq} / \mathrm{Cm}$ & 372 & $20 s p$ & $\mathrm{Bo} / \mathrm{Cm} / \mathrm{Bq}$ & 378 & 1 & $?$ & 299 & 5 & Sk & & & & 298 & 20 & Sd \\
\hline 327 & $20 s p$ & $?$ & 258 & 30 & $\mathrm{Sh} / \mathrm{Cm} / \mathrm{Bq}$ & 350 & $15 s p$ & $\mathrm{U} / \mathrm{Cm}$ & 3.72 & 2 & $\mathrm{Bo} / \mathrm{Ba} / \mathrm{Cm}$ & 2.85 & 1 & Sk & & & & 2.83 & 5 & So/OS \\
\hline 318 & 15Nsp & $\mathrm{C}_{\pi} / \mathrm{Bq}$ ? & 2.54 & 40 & $\mathrm{Sh} / \mathrm{Cm} / \mathrm{Bq}$ & 352 & $40 \mathrm{sp}$ & $\mathrm{U} / \mathrm{Bo} / \mathrm{Cm}$ & 3.59 & 15 & $\mathrm{U} / \mathrm{Cm}$ & 2.34 & 1 & SW/BO & & & & 2.73 & 30 & Sd \\
\hline 310 & 20 & Bo? & 2.49 & 20 & $\mathrm{~Bq} / \mathrm{Cm}$ & 3.40 & 20 & $\mathrm{U} / \mathrm{Bo} / \mathrm{cm} / \mathrm{Bg}$ & 3.52 & 40 & $\mathrm{u} / \mathrm{Bo} / \mathrm{Cm}$ & 2.19 & 1 & $S K / B O$ & & & & 2.48 & 30 & Sd/OS \\
\hline 299 & 15 & B & 2.47 & 5 & $\mathrm{Sh} / \mathrm{Cm} / \mathrm{Bq}$ & 321 & 40 & $\mathrm{U} / \mathrm{Cm} / \mathrm{Bq}$ & 340 & 20 & $\mathrm{U} / \mathrm{Bo} / \mathrm{Cm}$ & & & & & & & 2.26 & 5 & Sd \\
\hline 2.89 & $5 d$ & $\mathrm{Bd} / \mathrm{Cm}$ & 2.52 & 15 & $\mathrm{~Bq} / \mathrm{Cm}$ & 312 & 30 & $U / B O$ & 3.21 & 20 & $\mathrm{U} / \mathrm{Bo} / \mathrm{Cm}$ & & & & & & & 200 & 5 & Sd \\
\hline 2.85 & id & $\mathrm{Ba} / \mathrm{Cm} / \mathrm{DS}$ & 2.28 & 5 & $\mathrm{Sh} / \mathrm{Ba} / \mathrm{Cm}$ & 299 & 5 & $U / B Q$ & 3.12 & 20 & Bo & & & & & & & 2.05 & 10 & $\dot{S} / 0 S$ \\
\hline 2.73 & 5 & $\mathrm{~Bq}$ & 2.24 & 5 & $\mathrm{~B} / \mathrm{Cm}$ & 2.94 & 30 & Bo & 299 & 15 & $U / B q$ & & & & & & & 1.98 & 15 & $S D / 0 S$ \\
\hline 257 & Sind & $\mathrm{Bq} / \mathrm{cm} / \mathrm{OS}$ & 220 & 5 & $\mathrm{Bd} / \mathrm{Cm}$ & 2.92 & 30 & $\mathrm{U} / \mathrm{BO} / \mathrm{Bq}$ & 2.94 & 45 & Bo & & & & & & & $\$ .93$ & 10 & Sd \\
\hline 2.50 & 5nd & $\mathrm{Bq} / \mathrm{Cm} / \mathrm{DS}$ & 2.18 & 5 & $?$ & 274 & 15 & Bd & 292 & 45 & $\mathrm{U} / \mathrm{Bo} / \mathrm{Bq}$ & & & & & & & 1.86 & 10 & Sd \\
\hline 211 & 5 & $\mathrm{BQ} / \mathrm{Cm} / \mathrm{OS}$ & 2.17 & 5 & $B q$ & 2.00 & 15 & U/Bo & 2.69 & 10 & U/BO & & & & & & & $1 . \pi$ & 5 & So/tos \\
\hline 2.03 & 1 & $\mathrm{~Bq} / \mathrm{Cm} / \mathrm{OS}$ & 2.12 & 5 & Ba & 2.63 & 5 & U & 2.63 & 5 & U & & & & & & & 1.72 & 5 & St/OS \\
\hline 1.80 & 1 & $\mathrm{~cm} / \mathrm{OS}$ & 2.08 & 20 & $\mathrm{Sh} / \mathrm{Bq} / \mathrm{Cm}$ & 220 & 20 & $\mathrm{U} / \mathrm{Bo}_{0} / \mathrm{Cm}$ & 2.53 & 10 & $\mathrm{U} / \mathrm{Bo} / \mathrm{Bq} / \mathrm{Cm}$ & & & & & & & 1.65 & 20 & os \\
\hline & & & 2.06 & 20 & $\mathrm{Sh} / \mathrm{Cm} / \mathrm{Bq}$ & 2.10 & 15 & $\mathrm{U} / \mathrm{Bo} / \mathrm{Cm} / \mathrm{Bq}$ & 2.48 & 5 & $\mathrm{Ba} / \mathrm{Cm}$ & & & & & & & & & \\
\hline & & & 2.03 & 20 & $\mathrm{BQ} / \mathrm{Cm}$ & 2.05 & 10 & $\mathrm{U} / \mathrm{Bo} / \mathrm{Cm} / \mathrm{Bq}$ & 2.46 & 1 & $B o / B q$ & & & & & & & & & \\
\hline & & & 2.08 & 30 & $?$ & & & & 2.27 & 5 & $\mathrm{U} / \mathrm{Bo} / \mathrm{Bq} / \mathrm{Cm}$ & & & & & & & & & \\
\hline & & & 2.00 & 20 & $\mathrm{Sh} / \mathrm{Cm}$ & & & & 220 & 25 & $\mathrm{U} / \mathrm{BO} / \mathrm{Bq} / \mathrm{Cm}$ & & & & & & & & & \\
\hline & & & 1.98 & 20 & $\mathrm{Sh} / \mathrm{Cm}$ & & & & 2.10 & 15 & $\mathrm{U} / \mathrm{BO} / \mathrm{Ba} / \mathrm{cm}$ & & & & & & & & & \\
\hline & & & 1.93 & 20 & $\mathrm{~cm}$ & & & & 2.05 & 10 & $\mathrm{U} / \mathrm{Bo} / \mathrm{Cm}$ & & & & & & & & & \\
\hline & & & 1.92 & 20 & $?$ & & & & 1.990 & 1 & $\mathrm{Bo} / \mathrm{Cm}$ & & & & & & & & & \\
\hline & & & 1.85 & 20 & $\mathrm{Sh} / \mathrm{Cm}$ & & & & 1.960 & 5 & $\mathrm{Cm}$ & & & & & & & & & \\
\hline & & & 1.80 & 25 & $\mathrm{Sh} / \mathrm{Cm}$ & & & & 1.940 & 5 & $\mathrm{Bo} / \mathrm{Cm}$ & & & & & & & & & \\
\hline & & & & & & & & & 1.910 & 30 & $\mathbf{U}$ & & & & & & & & & \\
\hline & & & & & & & & & 1.870 & 5 & $\mathrm{U} / \mathrm{Bo} / \mathrm{Cm}$ & & & & & & & & & \\
\hline & & & & & & & & & 1.825 & 5 & U/Bo & & & & & & & & & \\
\hline $\begin{array}{l}\text { Sumr } \\
\mathrm{Cm} .\end{array}$ & $\begin{array}{l}\text { ory-1k } \\
\text { ninor B }\end{array}$ & $\begin{array}{l}\text { ostly bq and } \\
\text { b }\end{array}$ & $\begin{array}{l}\text { Summ } \\
\text { minor }\end{array}$ & $\mathrm{Cm}$ a & $\begin{array}{l}\text { ostly Sh with } \\
\text { od Bq }\end{array}$ & Summx & ory-Cm, & Bq. $U$ and $B 0$ & Summe & $y-80$ & U. $\mathrm{Cm}_{2}$ and $\mathrm{Bq}$ & $\begin{array}{l}\text { Summo } \\
\text { with } \mathrm{m}\end{array}$ & $\begin{array}{l}\text { iny-4k } \\
\text { inor } B\end{array}$ & sith Sk & $\begin{array}{l}\text { Summo } \\
\text { phose }\end{array}$ & $\begin{array}{l}\text { detect } \\
\text { detes }\end{array}$ & only & $\begin{array}{l}\text { Summo } \\
\text { with } m\end{array}$ & $\begin{array}{l}\text { iny-Uk } \\
\text { inor } 0\end{array}$ & $\begin{array}{l}\text { sthy Sd } \\
\text { S }\end{array}$ \\
\hline
\end{tabular}

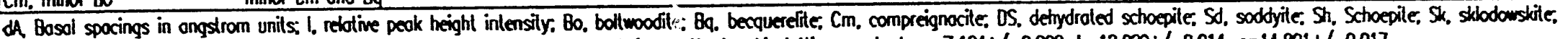

U. uronophane, greose, specimen mounting medium; : XRD lines indexed on derives orthorhombic lattice constonls $a=7.184+/-0.008, b=12.009+/-0.014, c=14.801+/-0.017$. 
Table 4b. Jaint Committee on Powder Diffraction Stondards (JCPOS) Indexing Lines Used to Identify X-Roy Peaks.

\begin{tabular}{|c|c|c|c|c|c|c|c|c|c|c|c|c|c|c|c|}
\hline \multicolumn{2}{|c|}{$\begin{array}{l}\text { Schoepite } \\
\text { KPOS 29-1376 }\end{array}$} & \multicolumn{2}{|c|}{$\begin{array}{l}\text { Becquerefile } \\
\text { UCPOS 29-399 } \\
\end{array}$} & \multicolumn{2}{|c|}{$\begin{array}{l}\text { Compreignocile } \\
\text { JCPDS 33-1049 } \\
\end{array}$} & \multicolumn{2}{|c|}{\begin{tabular}{|c|} 
Bolluoodite \\
CCPOS 29-1026 \\
\end{tabular}} & \multicolumn{2}{|c|}{$\begin{array}{l}\text { Uranophane } \\
\text { JCPDS 8-442 }\end{array}$} & \multicolumn{2}{|c|}{\begin{tabular}{|c|} 
Stlodowskite \\
SCPDS 29-875 \\
\end{tabular}} & \multicolumn{2}{|c|}{$\begin{array}{c}\text { Soddyite } \\
\text { ICPOS 35-491 }\end{array}$} & \multicolumn{2}{|c|}{$\begin{array}{l}\text { Dehyd.Schoepite } \\
\text { JCPOS 10-309 }\end{array}$} \\
\hline$d A$ & 1 & dA & 1 & dA & 1 & $d A$ & 1 & dA & 1 & $d A$ & 1 & dA & 1 & $d A$ & 1 \\
\hline 7.37 & 100 & 7.89 & 3 & 7.46 & 100 & 7.53 & 20 & 7.88 & 100 & 842 & 100 & 6.30 & 100 & 5.11 & 100 \\
\hline 6.65 & 20 & 7.49 & 100 & 6.23 & 3 & 6.81 & 100 & 6.61 & 40 & 6.37 & 20 & 4.81 & 70 & 3.45 & 80 \\
\hline 369 & 40 & 6.59 & 7 & 6.03 & 3 & 6.40 & 50 & 542 & 40 & 5.91 & 50 & 4.66 & 10 & 3.43 & 100 \\
\hline 359 & 100 & 6.25 & 4 & 5.71 & 3 & 5.45 & 50 & 4.76 & 50 & 4.82 & 40 & 4.56 & 100 & 2.86 & $\boldsymbol{6 0}$ \\
\hline 3.52 & 60 & 565 & 4 & 4.72 & 5 & 4.74 & 40 & 4.29 & 20 & 4.51 & 10 & 3.80 & 10 & 2.56 & 40 \\
\hline 324 & 80 & $4 \pi$ & $<2$ & 4.59 & 9 & 4.32 & 40 & 3.94 & 90 & 4.33 & 40 & 335 & 100 & 2.49 & 60 \\
\hline 3.17 & 50 & 4.71 & 4 & 371 & 80 & 4.11 & 20 & 3.60 & 40 & 4.19 & 80 & 326 & 40 & 2.14 & 40 \\
\hline 2.99 & 10 & 4.64 & 2 & 358 & 40 & 3.91 & 10 & 351 & 40 & 4.00 & 50 & 2.99 & 70 & 2.05 & 40 \\
\hline 2.78 & 10 & 4.44 & 3 & 3.53 & 60 & 3.75 & 10 & 341 & 10 & 3.52 & 60 & 2.81 & 40 & 1.99 & ED \\
\hline 2.58 & 30 & 384 & $<2$ & 3.38 & 5 & 3.54 & 70 & 3.35 & 10 & 327 & 70 & 2.72 & 100 & 1.97 & 40 \\
\hline 2.55 & 20 & 374 & 35 & 323 & 70 & 3.40 & 90 & 320 & 50 & 3.00 & 60 & 2.49 & 406 & 1.82 & 30 \\
\hline 2.46 & 5 & 302 & $<2$ & 320 & 90 & 3.13 & 50 & 3.09 & 10 & 2.87 & 50 & 2.48 & 10 & 1.78 & 40 \\
\hline 2.29 & 5 & 355 & 40 & 310 & 1 & 307 & 10 & 2.99 & 80 & 2.80 & 20 & 2.34 & 10 & 1.74 & 40 \\
\hline 226 & 10 & 345 & 20 & 3.04 & 3 & 2.91 & 70 & 2.91 & 80 & 2.74 & 20 & 2.26 & 10 & 1.72 & 20 \\
\hline 2.09 & 20 & 338 & 8 & 3.03 & 3 & 2.69 & 106 & 2.69 & 40 & 2.70 & 10 & 210 & 10 & 1.71 & 30 \\
\hline 200 & 30 & 321 & 80 & 2.89 & 5 & 2.53 & 30 & 2.63 & 50 & 2.66 & 10 & 2.05 & 10 & 1.70 & 20 \\
\hline 2.00 & 20 & 318 & $<2$ & 2.84 & 3 & 2.45 & 50 & 2.57 & 20 & 2.52 & 10 & 1.98 & 40 & 1.64 & 30 \\
\hline 1.98 & 30 & 316 & 30 & 2.82 & 5 & 2.34 & 40 & 2.52 & 20 & 2.34 & 20 & 1.91 & 40 & 1.63 & 30 \\
\hline 1.85 & 10 & 2.97 & 10 & 2.58 & 20 & 2.26 & 50 & 2.40 & 10 & 2.77 & 5 & 1.86 & 40 & & \\
\hline 1.82 & 20 & 2.91 & 5 & 2.56 & 35 & 2.21 & 40 & 2.26 & 20 & 2.22 & 20 & 1.77 & 10 & & \\
\hline 1.80 & 20 & 286 & 12 & 2.48 & 13 & 2.16 & 20 & & & 2.19 & 20 & 1.71 & 10 & & \\
\hline & & 272 & 10 & 2.37 & 3 & 2.13 & 30 & & & 2.17 & 20 & & & & \\
\hline & & 2.68 & $<2$ & 2.32 & 8 & 2.11 & 20 & & & 2.13 & 30 & & & & \\
\hline & & 2.59 & 8 & 2.29 & 3 & 2.08 & 10 & & & 2.09 & 30 & & & & \\
\hline & & 2.57 & 25 & 2.25 & 3 & 2.05 & 30 & & & & & & & & \\
\hline & & 2.55 & 10 & 2.22 & 4 & 1.994 & 20 & & & & & & & & \\
\hline & & 2.50 & 4 & 220 & 4 & 1.983 & 20 & & & & & & & & \\
\hline & & 249 & $<2$ & 2.09 & 6 & 1.950 & 30 & & & & & & & & \\
\hline & & 2.45 & 6 & 2.06 & 15 & 1.935 & 10 & & & & & & & & \\
\hline & & 2.39 & 3 & 2.03 & 不 & 1.900 & 600 & & & & & & & & \\
\hline & & 2.34 & 2 & 1.99 & 20 & 1.874 & 10 & & & & & & & & \\
\hline & & 2.30 & 10 & 1.96 & 10 & 1.820 & 20 & & & & & & & & \\
\hline & & 229 & 2 & 1.93 & 7 & 1.780 & 10 & & & & & & & & \\
\hline & & 2.25 & 2 & 1.88 & 1 & 1.764 & 60 & & & & & & & & \\
\hline & & 223 & 2 & 1.86 & 1 & 1.700 & 30 & & & & & & & & \\
\hline & & 2.21 & 10 & 1.80 & 12 & & & & & & & & & & \\
\hline & & 2.17 & 2 & 1.78 & 7 & & & & & & & & & & \\
\hline & & 2.12 & 8 & 1.77 & 3 & & & & & & & & & & \\
\hline & & 2.07 & 8 & & & & & & & & & & & & \\
\hline & & 2.04 & 25 & & & & & & & & & & & & \\
\hline
\end{tabular}

See lable 4a. 


\section{FIGURE CAPTIONS}

Figure 1. Schematic diagram of experinental assembly showing three-pellet sample configuration.

Figure 2. Cumulative release of uranium from experiments. Note the variations in vertical scale between experimental pairs. (a) \#1 and \#2 (11 $\mathrm{UO}_{2}$ discs; $0.075 \mathrm{~mL} / 3.5$ day): (b) \#3 and \#4 (crushed $\mathrm{UO}_{2}$ pellet; $0.075 \mathrm{~mL} / 3.5$ days); (c) \#5 and \#6 (three $\mathrm{UO}_{2}$ pellets; $0.075 \mathrm{~mL} / 3.5$ days); and (d) \#7 and \#8 (three $\mathrm{UO}_{2}$ pellets; $0.0375 \mathrm{~mL} / 7$ days). The darkened symbols are for tests that are terminated.

Figure 3. Top surface of sample \#5 after 3.5 years of reaction showing spatial distribution of secondary phases. (a) Reflected light image and (b) SEM backscatter electron image of northeast quadrant from Fig. $3 a$.

Figure 4. SEM photomicrographs of corroded $\mathrm{VO}_{2+x}$ surfaces. (a) Unaltered $\mathrm{UO}_{2}$ surface; (b) top surface of sample \#4 showing highly pitted grain surfaces and extensive intergrain boundary corrosion; (c) bottom surface of sample \#4 showing pitted grain surfaces and relatively minor intergrain boundary corrosion. Note "fresh" surface of grain in center where overlying grain has apparently been dislodged, exposing a new grain boundary surface; and (d) hummocky surface from sample \#5 showing extensive intergranular corrosion.

Figure 5. EDS spectra from various alteration phases formed on the sample surfaces. All spectra taken at $30 \mathrm{keV}$ accelerating potential.

(a) Unaltered $\mathrm{UO}_{2}$ surface showing pure U-oxide spectra;

(b) altered $\mathrm{UO}_{2+x}$ surface showing potential trace enrichment of $K_{i}$ (c) dehydrated schoepite showing pure U-oxide-hydrate spectra; (d) schoepite showing probable trace enrichment of $K_{i}$ (e) becquerelite displaying characteristic enrichment of $U$ and broad $\mathrm{Ca}$ shoulder to right of $\mathrm{UM}_{\alpha}$ and $\mathrm{UM}_{\beta}$ peaks; ( $f$ ) bladed soddyite crystals showing U-Si composition with trace $K_{i}$

(g) uranophane needles showing characteristic $U, S i$, and $\mathrm{Ca}$ peaks; (h) boltwoodite needles showing characteristic $U, S i$, and $K$ peaks; and (i) sklodowskite needles showing characteristic $U$, $\mathrm{Si}$, and $\mathrm{Mg}$ peaks.

Figure 6. SEM photomicrographs of various alteration phases. (a) Finegrained particulate matter deposited on surface of dehydrated schoepite crystals and underlying $\mathrm{UO}_{2+x}$ surface; (b) stellarshaped accumulation of dehydrated schoepite crystals from the top surface of sample \#8; (c) dehydrated schoepite crystals from the bottom surface of sample $\$$. Pitted surface of crystals is suggestive of a dissolution event for the schoepite phases:

(d) tabular books of schoepite picked from top of sample \#1;

(e) large tabular becquerelite crystal from the top of sample \#5 
showing development of dissolution pits. Also shown are individual and bunches of acicular uranophane crystals, and the granular $\mathrm{UO}_{2+x}$ surface; (f) bladed soddyite crystals from the top surface of sample \#5; (g) very fine-grained soddyite crystals from the top of sample \#5. EDS profiles show composition that is identical to the bladed crystals; (h) U-Si coating formed over unidentified blocky phase. The composition of the coating is similar to soddyite. The blocky crystal is completely dissolved away, but the morphology is similar to $\mathrm{UOH}$ minerals; (i) dense mat of uranophane bundles from top of sample \#5 showing exposed granular $\mathrm{UO}_{2+x}$ substrate to lower- and leftcenter portions of micrograph; $(j)$ stellar uranophane needles from top of sample \#5 developed on corroded $\mathrm{UO}_{2}+\mathrm{x}$ surface;

(k) acicular grains of sklodowskite (bright grains) developed on fluoropolymer substrate. From top surface of sample \#1;

(1) white teflon feather from the top surface of sample \#1. Uranium-rich particle appears in center of feather. Left side of photo taken in backscatter electron mode, right side with secondary electrons.

Figure 7. Interpretive paragenetic sequence formed on top surfaces of altered uraninite pellets. Onset of uranium dissolution and pulsed uranium release periods determined from solution data. Dotted lines represent suspected occurrence based on visual observations during periodic sampling intervals; dashed lines indicate both dissolution and precipitation occurring on different regions of the same surface; solid line indicates confirmed presence (by SEM and XRD) of mineral phase that is present in minor amounts; thickened line represents confirmed presence major mineral phase. 


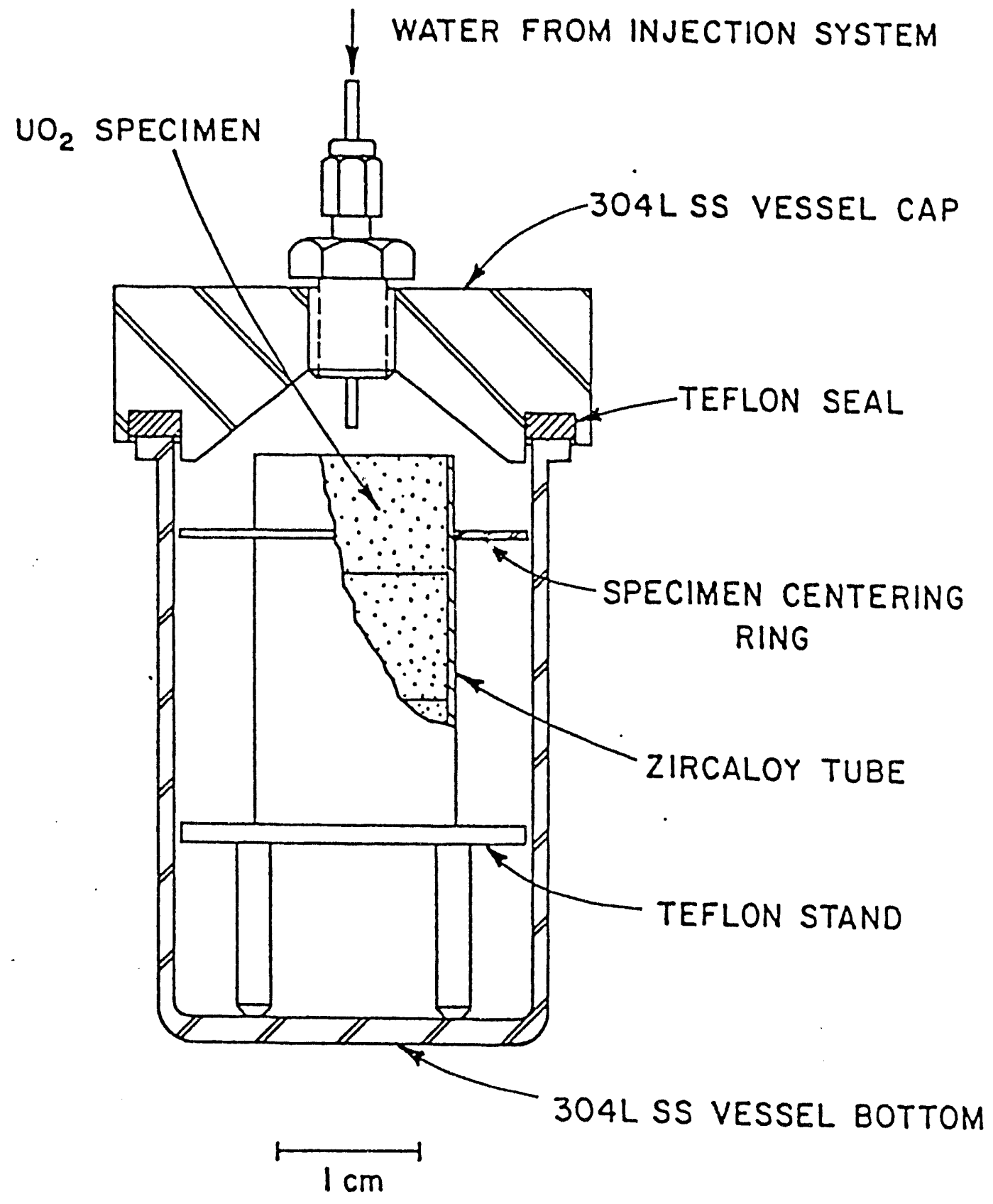

Fig. 1 
(a)

11-Disc Configuration

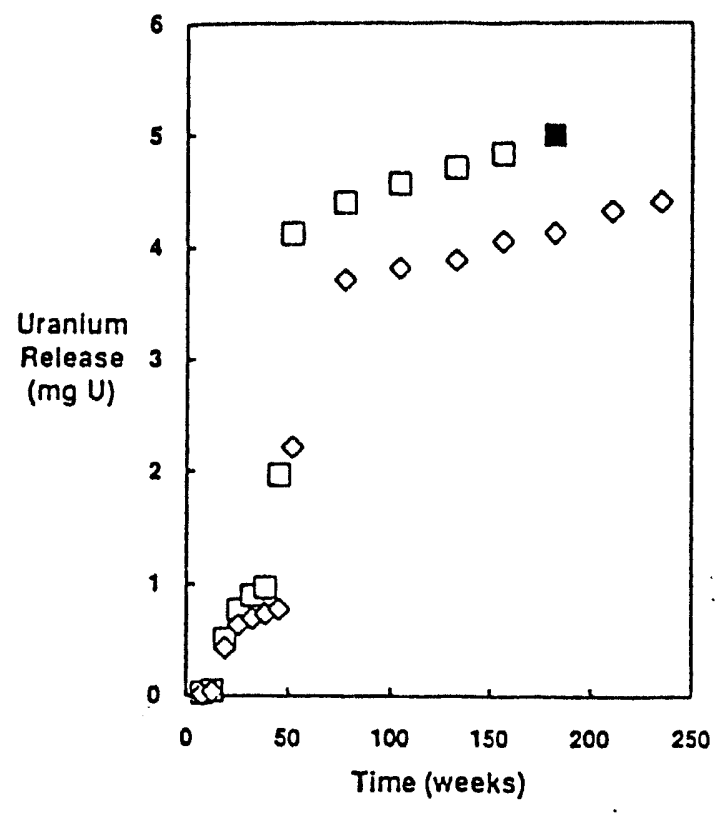

(c)

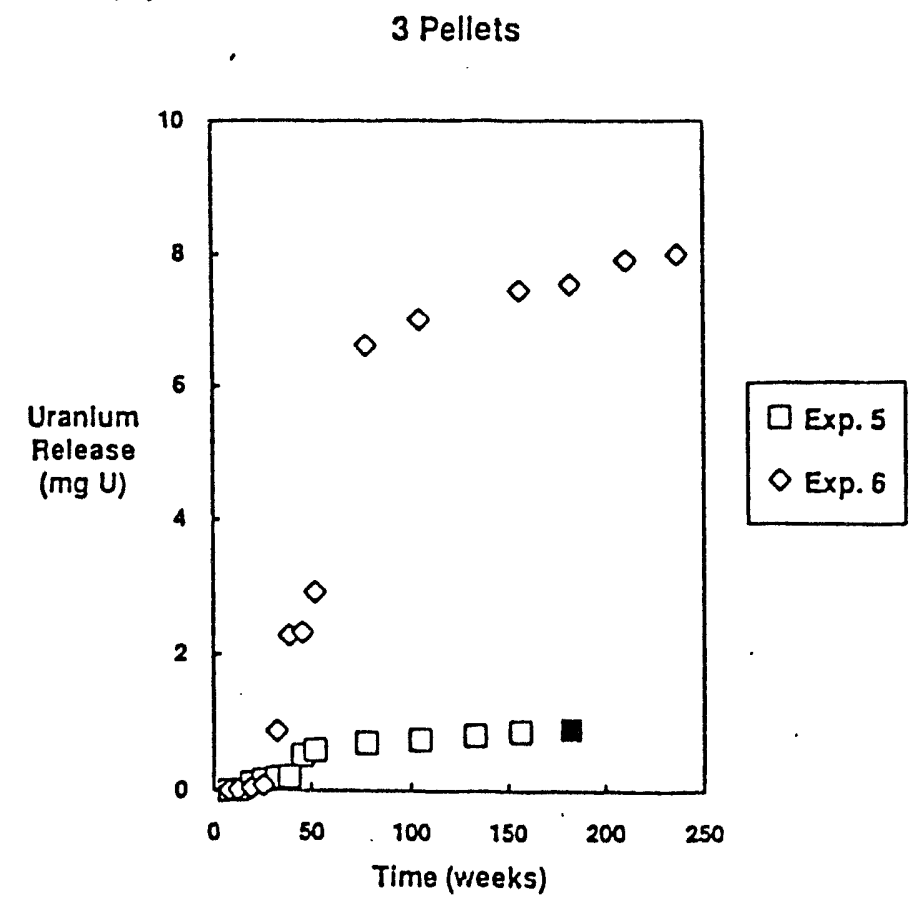

(b)

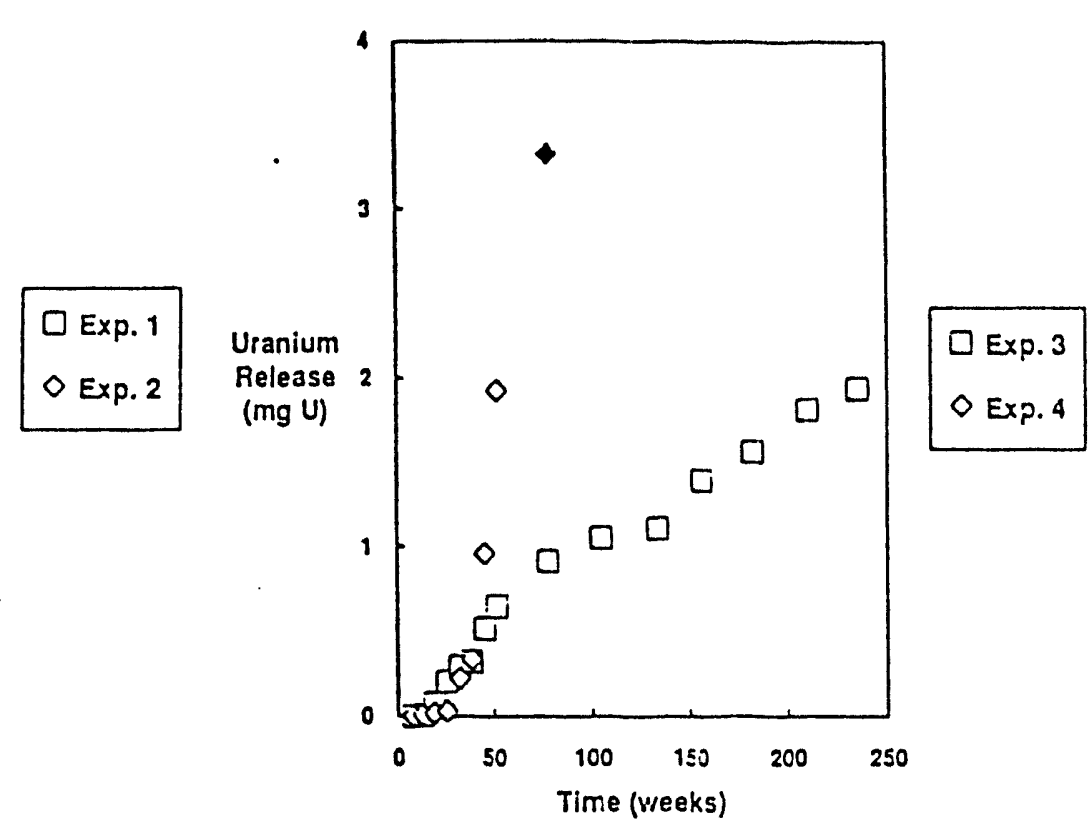

(d)

$$
\begin{gathered}
3 \text { Pellets } \\
\text { Reduced Water Flow }
\end{gathered}
$$

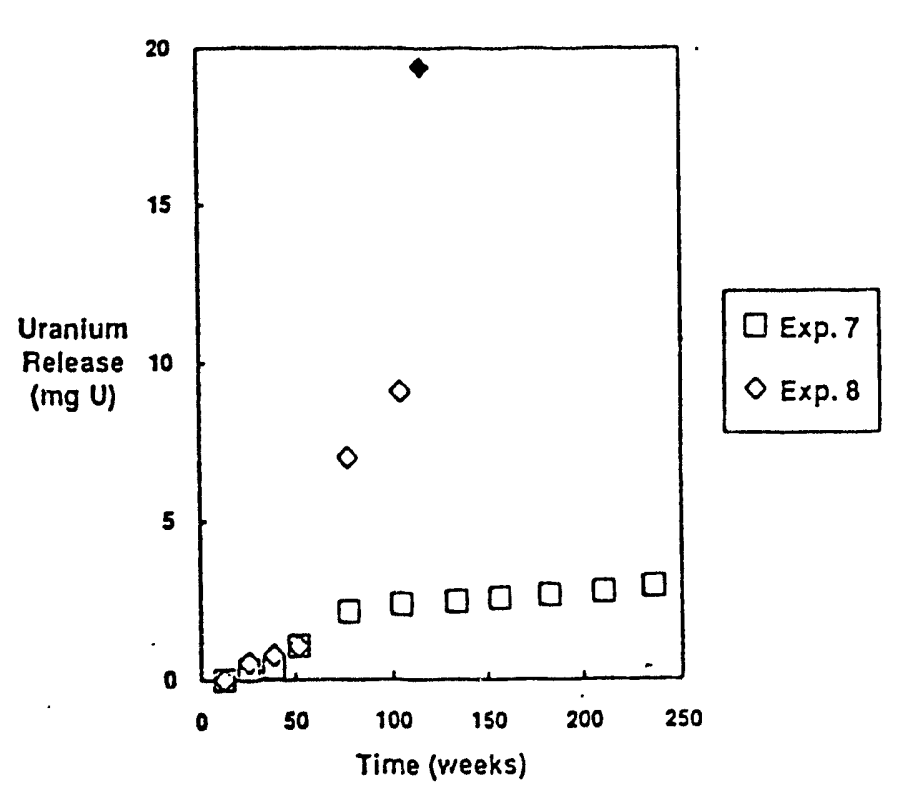

Fig. 2 

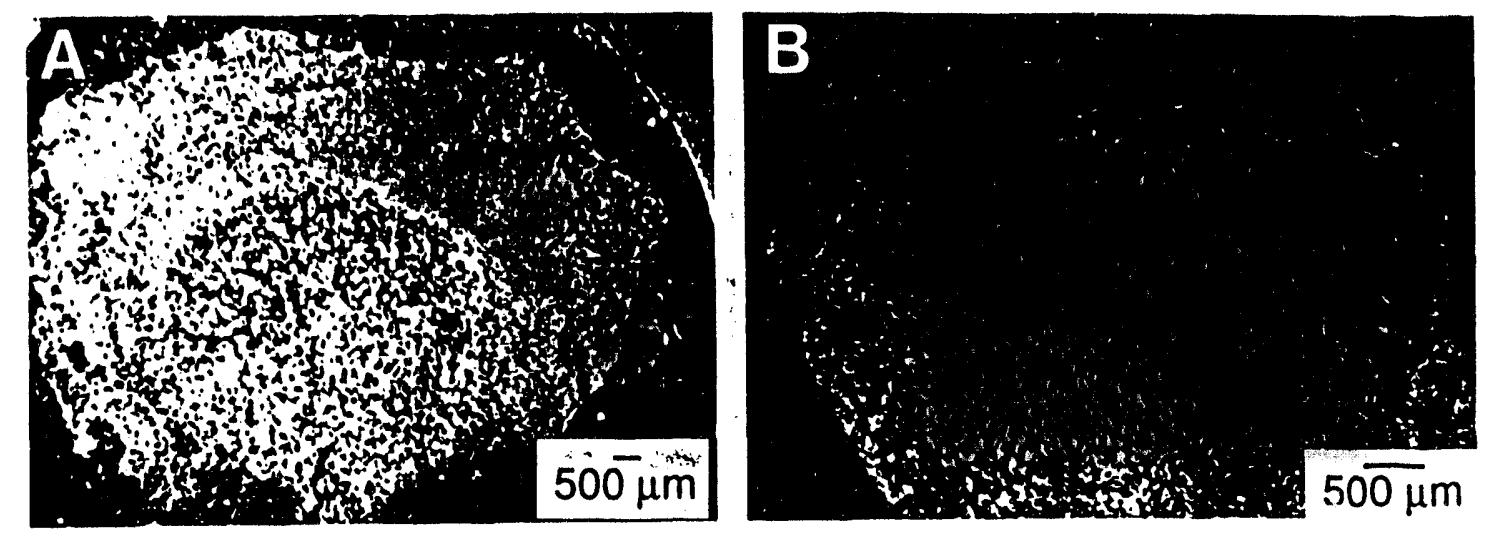


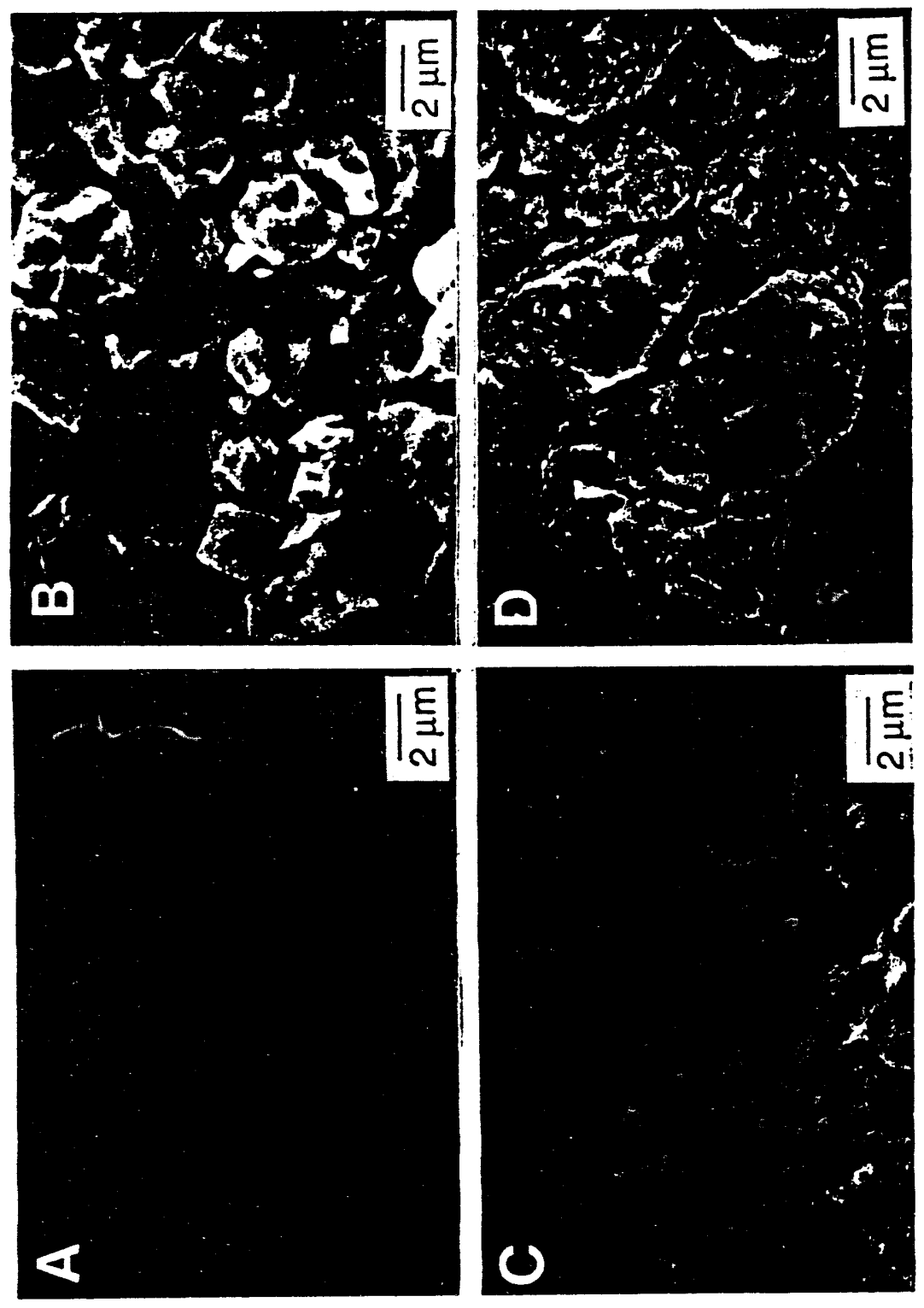



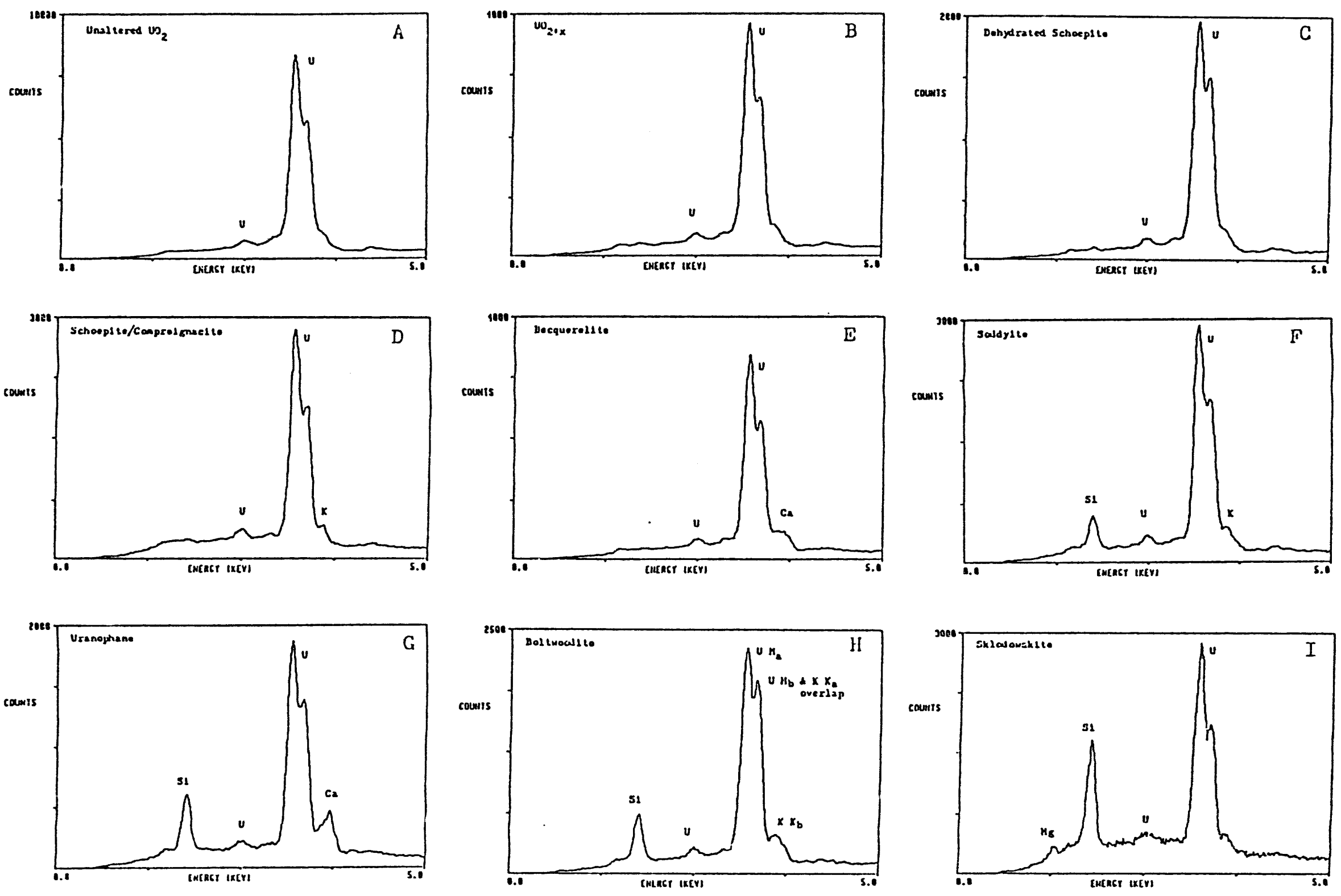

Fig. 5 

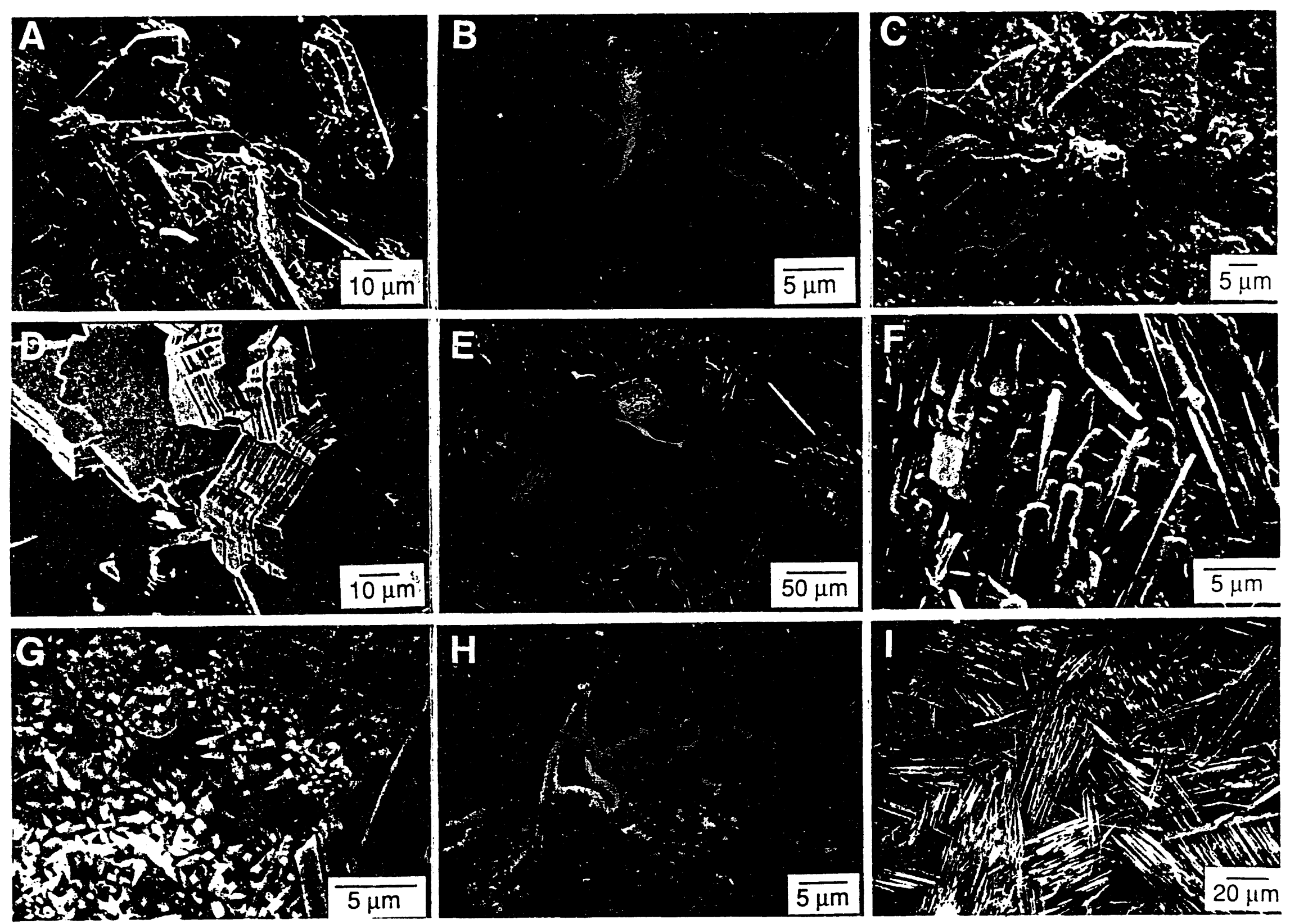


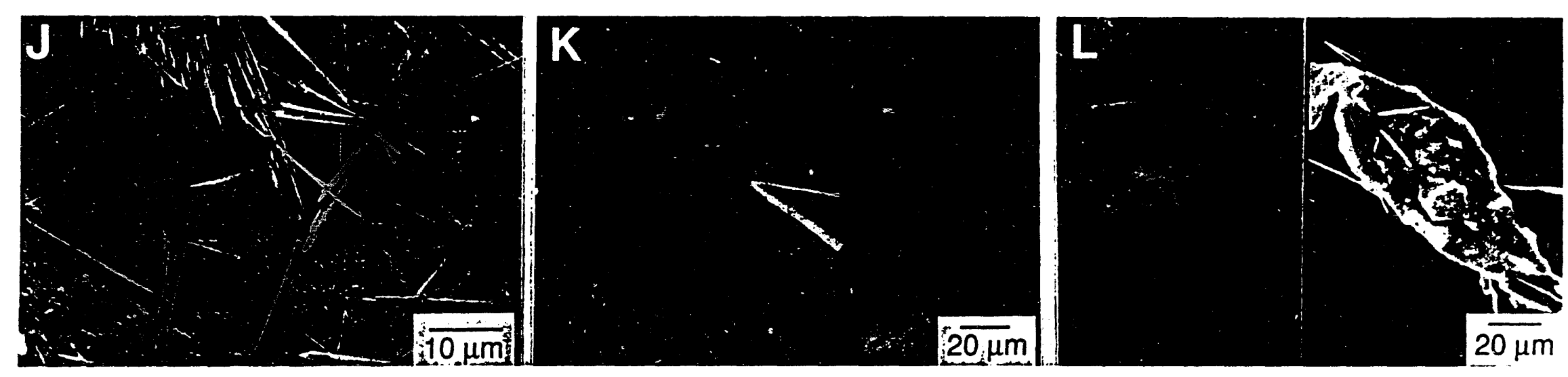




\section{EXPERIMENTAL PARAGENETIC SEQUENCE}

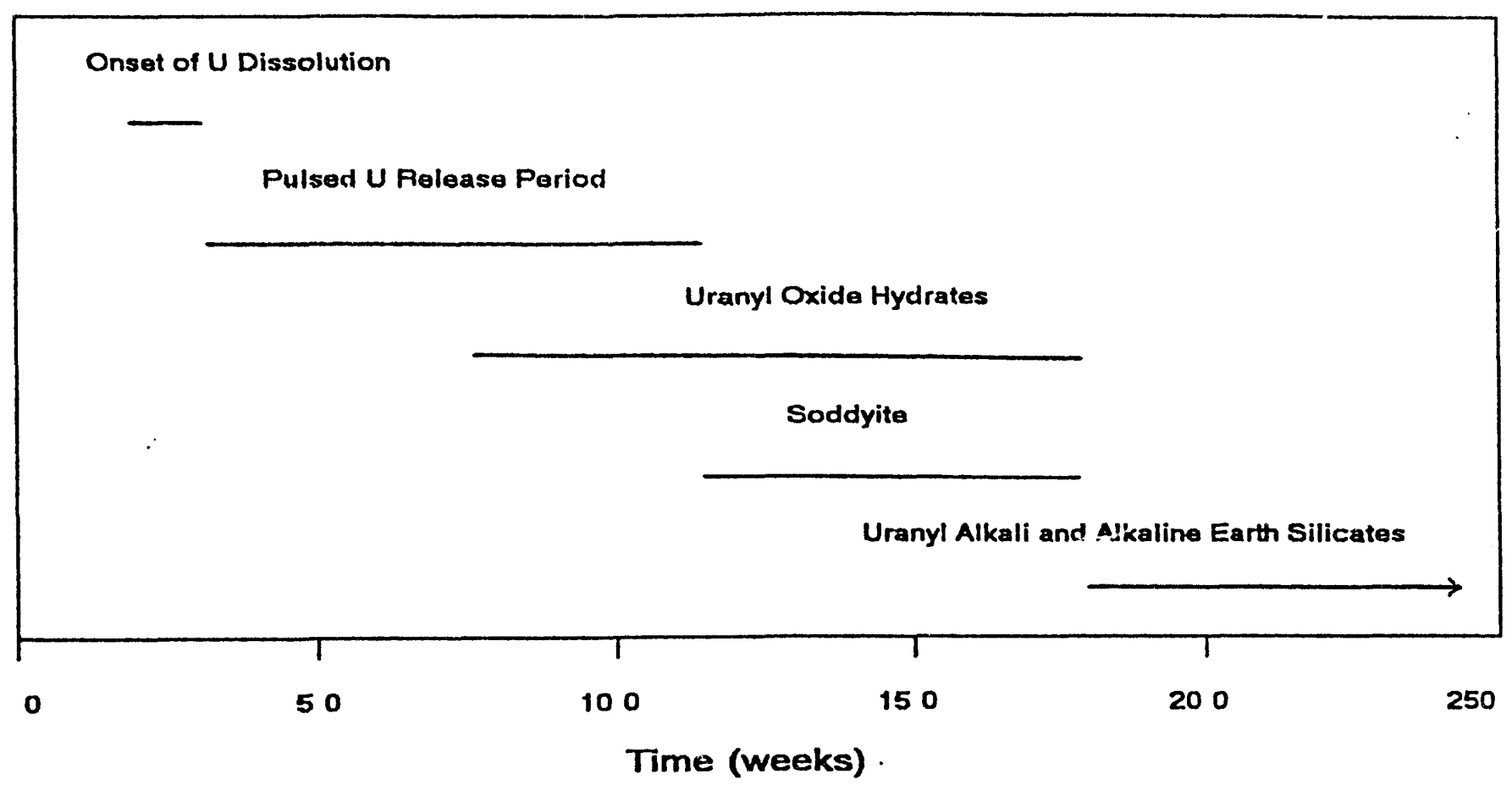

Fig. 7 

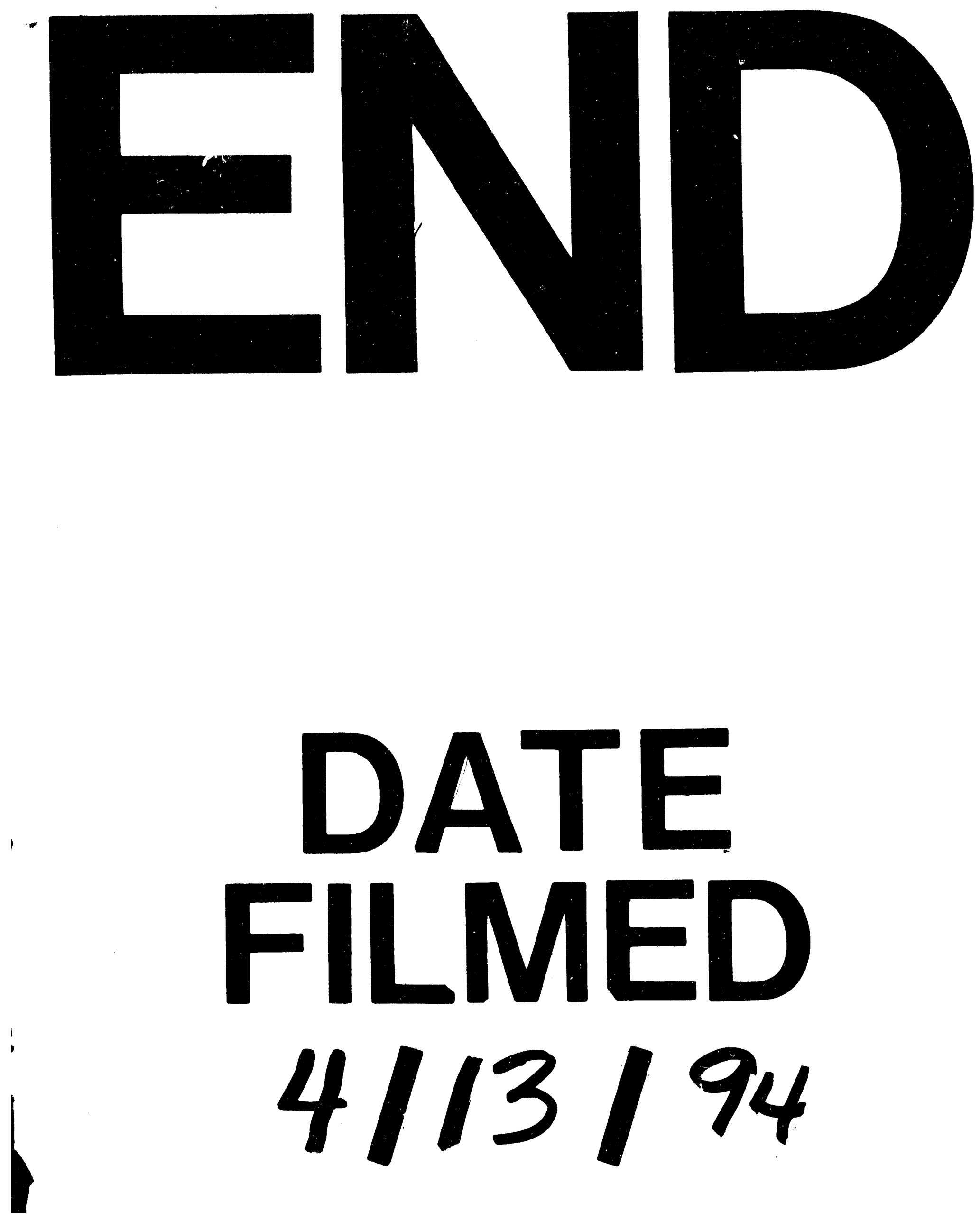
